\title{
SOX9 Is an Astrocyte-Specific Nuclear Marker in the Adult Brain Outside the Neurogenic Regions
}

\author{
๑Wei Sun, ${ }^{1}{ }^{\circledR}$ Adam Cornwell, ${ }^{1}$ Jiashu Li, ${ }^{1}{ }^{\oplus S i s i}$ Peng, ${ }^{1}$ M. Joana Osorio, ${ }^{1}$ Nadia Aalling, ${ }^{2}$ Su Wang, ${ }^{1}$ \\ Abdellatif Benraiss, ${ }^{1}$ Nanhong Lou, ${ }^{1}$ Steven A. Goldman, ${ }^{1,2}$ and ${ }^{\odot}$ Maiken Nedergaard ${ }^{1,2}$ \\ ${ }^{1}$ Center for Translational Neuromedicine, University of Rochester Medical Center, Rochester, New York 14642, and ${ }^{2}$ Center for Basic and Translational \\ Neuroscience, Faculty of Health and Medical Sciences, University of Copenhagen 2200 Copenhagen, Denmark
}

Astrocytes have in recent years become the focus of intense experimental interest, yet markers for their definitive identification remain both scarce and imperfect. Astrocytes may be recognized as such by their expression of glial fibrillary acidic protein, glutamine synthetase, glutamate transporter 1 (GLT1), aquaporin-4, aldehyde dehydrogenase 1 family member L1, and other proteins. However, these proteins may all be regulated both developmentally and functionally, restricting their utility. To identify a nuclear marker pathognomonic of astrocytic phenotype, we assessed differential RNA expression by FACS-purified adult astrocytes and, on that basis, evaluated the expression of the transcription factor SOX9 in both mouse and human brain. We found that SOX9 is almost exclusively expressed by astrocytes in the adult brain except for ependymal cells and in the neurogenic regions, where SOX9 is also expressed by neural progenitor cells. Transcriptome comparisons of SOX9+ cells with GLT1 + cells showed that the two populations of cells exhibit largely overlapping gene expression. Expression of SOX9 did not decrease during aging and was instead upregulated by reactive astrocytes in a number of settings, including a murine model of amyotrophic lateral sclerosis (SOD1G93A), middle cerebral artery occlusion, and multiple ministrokes. We quantified the relative number of astrocytes using the isotropic fractionator technique in combination with SOX9 immunolabeling. The analysis showed that SOX9+ astrocytes constitute $\sim 10-20 \%$ of the total cell number in most CNS regions, a smaller fraction of total cell number than previously estimated in the normal adult brain.

Key words: astrocyte marker; astrocytes; SOX9; transcriptome

Significance Statement

Astrocytes are traditionally identified immunohistochemically by antibodies that target cell-specific antigens in the cytosol or plasma membrane. We show here that SOX9 is an astrocyte-specific nuclear marker in all major areas of the CNS outside of the neurogenic regions. Based on SOX9 immunolabeling, we document that astrocytes constitute a smaller fraction of total cell number than previously estimated in the normal adult mouse brain.

\section{Introduction}

Astrocytes serve multiple functions, including modulating neuronal activity (Nedergaard, 1994; Parpura et al., 1994; Kang et al., 1998;

Received Oct. 15, 2016; revised Jan. 25, 2017; accepted Feb. 19, 2017.

Author contributions:W.S., S.A.G., and M.N. designed research;W.S., J.L.,S.P., N.A., and N.L. performed research; M.J.O., S.W., and A.B. contributed unpublished reagents/analytic tools; W.S. and A.C. analyzed data; W.S., A.C., S.A.G., and M.N. wrote the paper.

This work was supported by the National Institutes of Health and Adelson Medical Research Foundation (Grants R01NS075177 and HD076892 to M.N.) and the American Heart Association (Predoctoral Fellowship 12PRE12030048 to W.S.).

The authors declare no competing financial interests.

W. Sun's present address: Laboratory of Molecular and Cellular Neurobiology, National Institute of Mental Health, Bethesda, MD 20814.

Correspondence should be addressed to either Wei Sun or Maiken Nedergaard, Center for Translational Neuromedicine, University of Rochester Medical Center, 601 Elmwood Avenue, Box 645, Rochester, NY 14642. E-mail: wei.sun4@nih.gov or nedergaard@urmc.rochester.edu.

DOI:10.1523/JNEUROSCI.3199-16.2017

Copyright $\odot 2017$ the authors $\quad 0270-6474 / 17 / 374493-15 \$ 15.00 / 0$
Gourine et al., 2010; Takata et al., 2011), buffering potassium (Kuffler and Nicholls, 1966), taking up synaptic glutamate (Bergles and Jahr, 1997), maintaining endothelial tight junctions (Ballabh et al., 2004), and clearing brain metabolic waste products (Iliff et al., 2012). In fact, neurons have lost many basic cellular functions in the course of evolution and may depend on their symbiotic relationship with astrocytes for their function and survival. It is therefore not surprising that astrocytic dysfunction likely contributes to a host of neurological diseases, including Alzheimer's disease, epilepsy, Parkinson's disease, amyotrophic lateral sclerosis (ALS), and Huntington's disease (Benraiss et al., 2016; Verkhratsky et al., 2016), among others. However, the cellular composition of the central nervous system (CNS) is complex and identification of astrocytes, which are both morphologically and functionally heterogeneous, has been challenging. Currently, a few astrocyte markers are used routinely, including glial fibrillary acidic protein (GFAP), S100 calcium-binding protein B (S100 $\beta)$, glutamate transporter 1 (GLT1) (Rothstein et al., 1994), 
aquaporin-4 (AQP4), connexin-43 (Cx43), connexin-30 (Cx30) (Nagy et al., 1999), and, more recently, aldehyde dehydrogenase 1 family member L1 (ALDH1L1) (Cahoy et al., 2008). However, even though transcription factors play key roles in cellular differentiation and drive expression of phenotype-specific genetic programs, the expression of astrocytic transcription factors beyond early development has not been studied extensively.

Several recent studies have suggested that the transcription factor SOX9 is highly enriched in astrocytes (Pompolo and Harley, 2001; Lovatt et al., 2007; Barnabé-Heider et al., 2010; Molofsky et al., 2013; Zhang et al., 2014; Farmer et al., 2016; Nagao et al., 2016; Zhang et al., 2016). On that basis, here, we examined the expression pattern of SOX9 in both young and aged wild-type mice, as well as in several models of reactive astrogliosis, using genomics, immunohistochemistry, and transgenic reporter mice. Comparisons of the transcriptomes of SOX9+ cells and GLT1 + cells indicated that these two populations exhibited largely overlapping gene expression. Like other currently used astrocytic markers, SOX9 specifically labels astrocytes outside of the neurogenic regions: the subventricular zone (SVZ), the subgranular zone (SGZ) of the hippocampal dentate gyrus, and the rostral migratory stream (RMS) of the olfactory bulb. However, SOX9 also manifested several advantages in that respect, including that its expression was not diminished by age or functional status. It did not decrease during aging, remained nuclear in localization in mature astroglia, and was upregulated in scar tissue, all of which facilitated the identification of individual astrocytes. Indeed, quantification of the relative number of astrocytes, based on combining the isotropic fractionator technique with SOX9 immunolabeling (Herculano-Houzel and Lent, 2005), showed that SOX9+ astrocytes constitute only $\sim 10-20 \%$ of total cells in most CNS regions and that the relative percentage of SOX9+ astrocytes is even lower $(\sim 2-5 \%)$ in the olfactory bulb and cerebellum. These numbers are lower than typically reported, suggesting that use of a nuclear marker of astrocytic phenotype enables a more conservative assessment of astrocytic phenotype than that achieved previously using cytoplasmic markers, which do not permit such a highresolution assignment of individual cell identify.

\section{Materials and Methods}

Mice. Wild-type mice (C57BL/6J; The Jackson Laboratory), SOD1 G93A mice (The Jackson Laboratory, stock \#004435), BAC-GLT1-EGFP mice (GLT1-EGFP, previously generated from Dr. Jeffrey D. Rothstein's laboratory; Regan et al., 2007), BAC-ALDH1L1-EGFP mice (ALDH1L1EGFP, kind gift from Dr. Jeffrey D. Rothstein's laboratory), SOX9-EGFP mice (University of California Davis MMRRC, strain 011019-UCD), PDGFRA-EGFP mice (The Jackson Laboratory, stock \#007669) were used in this study. All mice were 2-4 months old unless otherwise stated. All experiments were approved by the University Committee on Animal Resources of the University of Rochester and performed according to guidelines from the National Institutes of Health.

Human samples. Human cortical tissue was obtained from surgical specimens from patients with hippocampal malformations and absence of gliosis in the surgically removed cortical tissue. Tissue samples were collected with informed consent and tissue donation approval under protocols approved by the Research Subjects Review Board of the University of Rochester Medical Center. For transcriptome studies, tissue was kept on ice after harvest and dissociated immediately. For immunofluorescent microscopy, tissue was immediately put in 4\% PFA solution and fixed for a maximum of $24 \mathrm{~h}$. Samples with excessive or disorganized GFAP + processes on histological analysis were excluded to avoid possible reactive gliosis.

Dissociation of human and mouse brain tissue followed by FACS. Dissociation of the human and mouse cortical tissue was performed as described previously (Lovatt et al., 2007) with minor modifications. Wild-type mice or GLT1-EGFP mice were anesthetized with pentobarbital $\left(50 \mathrm{mg} \mathrm{kg}^{-1}\right.$, i.p.), perfused with cold HBSS, and decapitated. The brain was immediately removed and cortex was dissected and cut into small pieces, which were digested with $5 \mathrm{U} / \mathrm{ml}$ papain in $\mathrm{Ca}^{2+} / \mathrm{Mg}^{2+}$-free PIPES/cysteine buffer, $\mathrm{pH}$ 7.4 , for $1 \mathrm{~h}$ at $37^{\circ} \mathrm{C} / 5 \% \mathrm{CO}_{2}$. After one wash, the tissue was then further digested with $40 \mathrm{U} / \mathrm{ml}$ DNase I in $\mathrm{Mg}^{2+}$-containing MEM with $1 \%$ bovine serum albumin (BSA) for $15 \mathrm{~min}$ at $37^{\circ} \mathrm{C} / 5 \% \mathrm{CO}_{2}$. The tissue was then carefully triturated in cold MEM with $1 \%$ BSA and centrifuged over a $90 \%$ Percoll gradient. Cells below and included in the lipid layer were collected, washed, and centrifuged to collect the cell pellet. For wild-type mice, the cells were labeled with rabbit anti-GLT1 antibody (1:150, custom made; Invitrogen) or rabbit IgG control followed by labeling with secondary donkey antirabbit allophycocyanin (APC) (1:200). Cells were resuspended in cold MEM with $1 \%$ BSA containing $5 \mu \mathrm{g} / \mathrm{ml} 4^{\prime}$,6-diamidino-2-phenylindole (DAPI) to discriminate dead cells

Cells were sorted using BD FACSAria III Cell Sorting System immediately. Single cells were discriminated using pulse width and height measurements. APC was excited by a $633 \mathrm{~nm}$ laser, and emissions were collected by a $660 / 20 \mathrm{~nm}$ band-pass filter. EGFP was excited by a 488 laser and emissions were collected by a 530/30 $\mathrm{nm}$ band-pass filter and DAPI was excited by a $407 \mathrm{~nm}$ laser and emissions were collected by a $450 / 40$ band-pass filter. Dead cells were excluded according to positive DAPI signal. GLT1 + and GLT1 - populations were gated according to isotype control. Cells were sorted into cold MEM containing 1\% BSA.

RNA processing, microarray, and quantitative PCR ( $q P C R)$. After FACS, cells were immediately extracted for total RNA using either the RNAqueous Micro kit (Life Technologies) or RNeasy Micro Kit (Qiagen). Mouse cortical and spinal cord tissue samples were collected after transcardial perfusion of ice-cold HBSS and RNA was extracted with RNeasy Plus Universal Mini Kit (Qiagen). RNA quantity was assessed using the NanoDrop 1000 and RNA integrity was assessed using an Agilent Bioanalyzer 2100. For microarray, $20 \mathrm{ng}$ of total RNA was amplified and labeled with biotin using the Ovation kit according to the manufacturer's instructions and hybridized to the Affymetrix GeneChip Mouse Genome 4302.0 Array. For qPCR, total RNA was either reverse transcribed with TaqMan Reverse Transcription Reagents or amplified using Nugen Ovation RNA Amplification System V2. Relative quantity of transcripts was assessed using Taqman Assays on Demand and the 7000 Sequence Detection System. 18S RNA or Gapdh served as an internal control that all samples were normalized to before calculating relative expression.

Focal cerebral ischemia (middle cerebral artery occlusion, MCAO). Adult male mice were anesthetized with $3 \%$ isoflurane for induction and $1.5 \%$ isoflurane for maintenance in $70 \% \mathrm{~N}_{2} \mathrm{O} / 30 \% \mathrm{O}_{2}$ via a face mask. Right MCA was occluded for 45 min by a 7-0 polypropylene monofilament (Ethicon) coated with silicon resin was inserted through the external carotid artery to the origin of the MCA. Cortical blood flow was continuously monitored by laser Doppler flowmetry probe positioned $2 \mathrm{~mm}$ posterior and $5 \mathrm{~mm}$ lateral from the bregma (Perimed). Rectal temperature was maintained at $37 \pm 0.5^{\circ} \mathrm{C}$ using a feedback controlled heating system (Harvard Apparatus).

Multiple ministroke model. Cholesterol crystals (Sigma-Aldrich) sized $40-70 \mu \mathrm{m}$ were collected as described previously (Wang et al., 2012). Mice were anesthetized with ketamine and xylazine $(50$ and $10 \mathrm{mg} / \mathrm{kg}$, i.p). The right common carotid artery (CCA), internal carotid artery (ICA), and external carotid artery (ECA) were carefully isolated under a dissecting microscope. The extracranial branch of the ICA was ligated with a $7-0$ suture and the distal portion of the ECA was permanently ligated. Microvascular clips were applied to the CCA and the proximal parts of the ECA and ICA and an incision was made between the ECA ligation site and the ECA clip. Polyethylene (PE10) tubing was inserted into the ECA toward the CCA and the microvascular clips were removed to restore blood flow. A total of $3500 \pm 500$ cholesterol crystals in $100 \mu \mathrm{l}$ of saline or $100 \mu \mathrm{l}$ of saline alone (for sham animals) were injected via the PE10 tubing. After injection, the tube was removed and the proximal ECA was permanently ligated and the wound closed. After stroke induction, animals were alert and moving within $2 \mathrm{~h}$ and were closely monitored for the first $12 \mathrm{~h}$ after stroke.

Immunofluorescence and confocal microscopy. Mice were anesthetized with ketamine $(100 \mathrm{mg} / \mathrm{kg}$, i.p.) and xylazine $(10 \mathrm{mg} / \mathrm{kg}$, i.p. $)$ and tran- 
scardially perfused with $0.01 \mathrm{M}$ PBS solution followed by $4 \%$ PFA in $0.01 \mathrm{M}$ PBS. Mouse brain and spinal cord tissue, as well as human cortical tissue, were postfixed in 4\% PFA for a maximum of $24 \mathrm{~h}$. For retina, the postfixation was $1 \mathrm{~h}$. The tissue was then dehydrated for $48 \mathrm{~h}$ with $30 \%$ sucrose in PBS solution, flash-frozen in optimal cutting temperature medium (Tissue-Tek), and cut into $20 \mu \mathrm{m}$ cryostat sections. Sections were washed with $0.01 \mathrm{M}$ PBS before incubating in blocking solution containing 10\% normal donkey serum (NDS) (Jackson ImmunoResearch Laboratories), 0.5\% Triton X-100 (Sigma-Aldrich), and $0.01 \mathrm{M}$ PBS. Sections were then incubated in primary antibody in blocking solution overnight at $4^{\circ} \mathrm{C}$. Primary antibodies used included mouse monoclonal anti-GFAP (mAB360; 1:500; Millipore), rabbit anti-SOX9 (sc-20095; 1:200; Santa Cruz Biotechnology), goat anti SOX9 (AF3075; 1:200; R\&D Systems), mouse anti-HuD (A21271; 1:200; Invitrogen), rabbit anti-tyrosine hydroxylase (AB152; 1:400; Millipore), and rabbit anti NeuN (ABN78; 1:400; Millipore). Sections were then washed with $0.01 \mathrm{M}$ PBS and incubated in Alexa Fluor-conjugated secondary antibodies (1:500; Life Technologies) and then mounted in ProLong Gold Antifade Mountant with DAPI (Life Technologies). Images were collected with a confocal laser-scanning microscope (FV500; Olympus). For quantification of the proportion of SOX9 + cells in the GLT1+ pool, the SOX9 channel was first made invisible and GLT1+ cells that also exhibited nuclei (DAPI+) were labeled and counted (as the denominator). The GLT1 channel was then made invisible while SOX9+ cells that were also labeled as GLT1 + were counted (as the numerator). The same method was used to calculate the proportion of GLT1+ cells in the SOX9 pool. For comparison of SOX9 and GFAP levels between wild-type mice and SOD1 G93A, sections were processed in parallel and images were collected with exactly the same setting between pairs of samples.

Western blotting. Mice were anesthetized with ketamine $(100 \mathrm{mg} / \mathrm{kg}$, i.p.) and xylazine (10 mg/kg, i.p.) and transcardially perfused with icecold HBSS. Cortical or spinal cord tissues were collected and snap-frozen on dry ice. Tissue was lysed in RIPA buffer (Thermo Scientific) with EDTA-free protease inhibitor cocktails (Thermo Scientific) by disruption with a Bullet Blende homogenizer (Next Advance) and then incubated for $15 \mathrm{~min}$ on ice. After centrifugation at $12,000 \times \mathrm{g}$ for $15 \mathrm{~min}$, the protein concentration was quantified using the Pierce BCA protein assay kit. Protein samples were separated by $4-12 \%$ Bis-Tris Gel (Life Technologies), transferred to PVDF membranes (Life Technologies), and blocked in 5\% nonfat dry milk (Bio-Rad) for $1 \mathrm{~h}$ before incubation with primary antibodies against SOX9 (sc-20095, 1:500; Santa Cruz Biotechnology), GFAP (mAB360; 1:2000; Millipore), ALDH1L1 (ab87117, 1:500; Abcam) and $\beta$-actin (A5441, 1:2000; Sigma-Aldrich) at $4^{\circ} \mathrm{C}$ overnight. Membranes were then washed and further incubated in blocking solution with IRDye secondary antibodies (Li-Cor) and imaged with Odyssey imager (Li-Cor). Fluorescent images were transformed into gray scale and protein abundance was evaluated by analyzing the intensity using the ImageJ program.

Isotropic fractionator and flow cytometry. Mice were anesthetized with ketamine (100 mg/kg, i.p.) plus xylazine (10 mg/kg, i.p.) and transcardially perfused with $0.01 \mathrm{~m}$ PBS solution followed by $4 \%$ PFA in $0.01 \mathrm{M}$ PBS. Mouse brain and spinal cord tissue, were postfixed in 4\% PFA for $24 \mathrm{~h}$. Fixation of no more than $24 \mathrm{~h}$ was critical for antibody recognition of SOX9. The meninges were removed and the tissue was dissected into six parts: olfactory bulb, cerebral cortex, hippocampus, cerebellum, the rest of the brain, and the spinal cord. The tissue was then processed to achieve a single nuclei suspension as described previously (Herculano-Houzel and Lent, 2005). Briefly, single pieces of tissue were homogenized in a hypotonic solution ( $40 \mathrm{~mm}$ sodium citrate and $1 \%$ Triton X-100) with a $7 \mathrm{ml}$ glass Tenbroeck tissue homogenizer until the smallest visible fragments were dissolved. The homogenate was then transferred to a $50 \mathrm{ml}$ centrifuge tube and centrifuged for $10 \mathrm{~min}$ at $4000 \times \mathrm{g}$. The pellet was resuspended with PBS containing $1 \%$ BSA. The nuclear suspension was stained with DAPI $(1 \mu \mathrm{g} / \mathrm{ml})$ and counted under a fluorescent microscope using a hemocytometer. Aliquots containing $5 \times 10^{6}$ nuclei from each sample were immunostained for either SOX9 (AF3075, 1:200; R\&D Systems) or NeuN (ABN78, 1:400; Millipore) overnight, washed with PBS containing $1 \% \mathrm{BSA}$, and then incubated with APC-conjugated sec- ondary antibodies (1:200; Jackson ImmunoResearch Laboratories) for $1 \mathrm{~h}$ in PBS containing 10\% NDS.

A BD Biosciences FACSAria III cell-sorting system was used to quantify the proportion of APC + cells. First, the single nuclei population was identified by the fluorescent intensity of DAPI and then this population was further analyzed in a FSC-A versus APC-A plot. A positive population was defined by its distinct distribution and increased fluorescent intensity compared with control samples (stained with only secondary antibodies). APC was excited by a $633 \mathrm{~nm}$ laser and emissions were collected by a $660 / 20 \mathrm{~nm}$ band-pass filter. DAPI was excited by a $407 \mathrm{~nm}$ laser and emissions were collected by a $450 / 40$ band-pass filter. The data were then further analyzed using FlowJo software.

Microarray data analysis. Microarray data were analyzed using GeneSpring GX Software. The data were normalized using the MAS5 algorithm, followed by $\log _{2}$ transformation. To ensure reproducibility among independent biological replicates in the genomic dataset, the correlation coefficient was compared within groups of sorted cells. The degree of similarity across all samples was assessed by hierarchical clustering using Euclidean average distances. Signal intensity values for probes of interest were further analyzed and visualized using GraphPad Prism software.

RNA-seq data analysis. Total RNA was prepared for sequencing with the Illumina TruSeq library prep kit and sequenced on an Illumina HiSeq 2500 (v4 chemistry) in paired-end mode with 125 bp read length. Sequencing yielded an average of 29.4 and 38.6 million $2 \times 125$ bp reads for Glt1+/Glt1 - and Sox9+/Sox9-, respectively. Reads were trimmed with Trimmomatic to exclude any remaining adapter sequence, as well as regions of low quality base calls that are sometimes observed at the end of reads. Quality was assessed for each sample with FastQC before and after trimming. Cleaned reads were aligned with STAR to the mouse genome (GRCm38.p3) with annotation incorporated from Gencode Genes (version M5). Transcript quantification to obtain gene-level TPM (transcripts per kilobase million) values was performed with RSEM and reads overlapping annotated features were counted with FeatureCounts from the Subread package. Count and expression data were read into R statistical software and filtered to exclude features aside from protein-coding genes and lncRNAs. Further filtering was done to exclude unexpressed genes by removing those with counts $<10$ across all samples. This filtered subset of genes was then used to examine the clustering, marker expression, and correlation patterns between the sample groups in the R statistical software environment with packages from Bioconductor.

\section{Results}

\section{SOX9 mRNA is enriched in astrocytes}

Mature astrocytes were acutely purified from adult brain tissue as described previously (Sun et al., 2013) based on GLT1 expression. Astrocyte transcriptome data were generated by both microarray for human astrocytes and RNA-seq for mouse cells and used to compare Sox9 expression with other frequently used astrocyte markers, including Aldh1l1, Aqp4, Gfap, Gja1, S100ß, and Slc1a2. Microarray analysis showed that human cortical GLT1+ cells were $18.8 \pm 7.1$-fold enriched in SOX9 mRNA compared with GLT1 - cells. Enrichment of other markers ranged from 4.5-fold $(S 100 B)$ to 288.6 -fold (AQP4). The enrichment of SOX9 was analogous to that of ALDH1L1, GFAP, GJA1, and S100B, but significantly less than that of AQP4 $(p=0.0052, n=3)$ and SLC1A2 ( $p=0.0326, n=3)$ (Fig. 1A). In mouse GLT1+ cells, RNA-seq analysis showed that Sox9 mRNA was (30.1 \pm 7.6$)$-fold enriched compared with GLT1 - cells. Other markers were enriched in GLT1 + cells between 8.9-fold (Gja1, Connexin-43) and 297.2-fold (Slc1a2, GLT1). Sox9 enrichment level was significantly lower than Aqp4 ( $p=0.0002, n=3)$, Gjal $(p=0.0005$, $n=3)$, and Slc1a2 $(p=0.0001, n=3)$ in mouse cortical GLT1+ cells and significantly higher than $\operatorname{S100} \beta(p=0.0004, n=3)$ (Fig. $1 B)$. Next, to verify RNA-seq findings, RNA from acutely isolated GLT1 + and GLT1 - cells were collected for qPCR analysis (Fig. 1C). Sox9 was $(8.3 \pm 0.9)$-fold enriched in the GLT1 + popula- 
A Human microarray

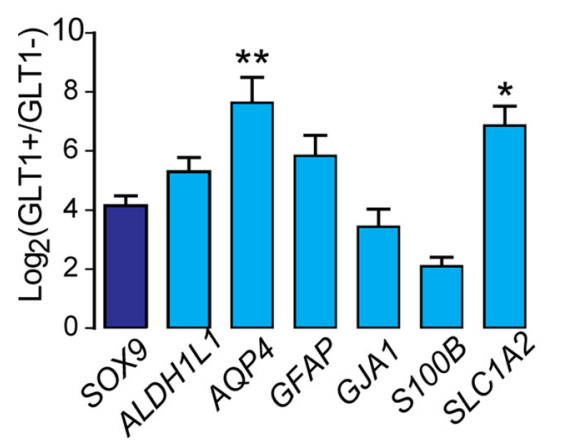

B

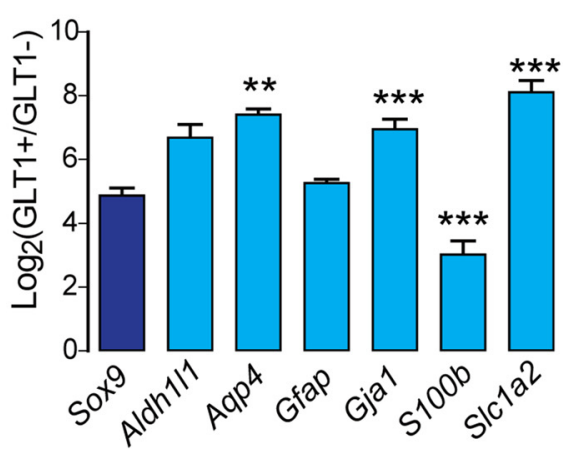

C

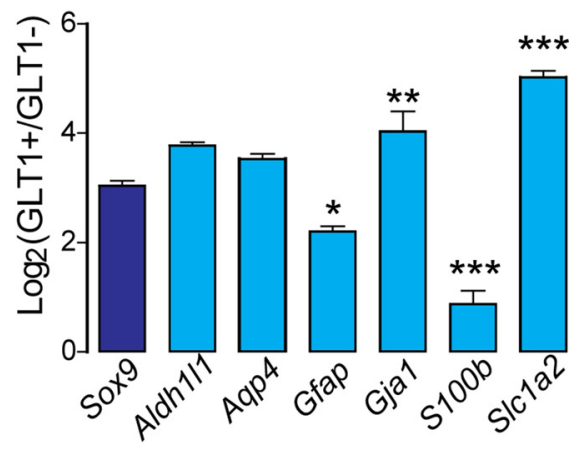

Figure 1. RNA enrichment of Sox9 and other astrocyte markers in acutely isolated adult astrocytes. $\boldsymbol{A}$, Microarray analysis of acutely isolated human astrocytes (GLT1+ cells) compared with astrocytes-depleted population (GLT1 -). The ratios (GLT1+/GLT1 -) of MAS5 normalized signal intensities are displayed on a log2 scale ( $y$-axis) and represent the enrichment levels for each marker gene ( $x$-axis) in human astrocytes. $\boldsymbol{B}$, RNA-seq analysis of acutely purified mouse astrocytes (GLT1+ cells) compared with mouse astrocyte depleted population (GLT1-). The ratios $(G L T 1+/ G L T 1-)$ of TPM counts are displayed on a log2 scale and represent the enrichment for each gene in mouse astrocytes. C, qPCR analysis on mouse cortical GLT1 + cells versus GLT1 - cells. The relative quantification method was used for data analysis. Relative expression units are calculated by using Gapdh as an internal control. Log2-transformed ratios are shown. Error bars indicate SD. $n=3 ;{ }^{*} p<0.05 ;{ }^{* *} p<0.01 ;{ }^{* * *} p<0.001$, one-way ANOVA followed by Bonferroni multiple-comparisons test.

tion, analogous to the relative enrichment of Aldh1l1 and Aqp4. The enrichment was significantly higher than that of Gfap ( $p=$ $0.0211, n=3)$ and $S 100 \beta(p=0.0001, n=3)$, yet lower than Slc1a2 $(p=0.0001, n=3)$ and Gja1 $(p=0.0047, n=3)$. Therefore, transcriptome and qPCR analyses indicated that Sox9 mRNA is highly enriched in astrocytes to an extent comparable to other canonical astrocyte markers.

\section{Overlapping of SOX9 and GLT1 in major CNS regions}

Next, we determined the percentage of astrocytes that express SOX9 and whether SOX9 expression is specific to astrocytes. We took advantage of the GLT1-EGFP mouse, in which EGFP expression is almost exclusively in astrocytes (Regan et al., 2007; Scott et al., 2010). In addition, GLT1 tags a broader population of astrocytes than GFAP in mouse CNS (Lovatt et al., 2007). GLT1 expression has been shown to largely overlap with that of another astrocyte marker, ALDH1L1 (Yang et al., 2011). Immunofluorescence labeling against SOX9 in slices prepared from GLT1-EGFP mouse brain and spinal cord sections was performed and quantified blindly using SOX9 antibodies from different vendors. Because SOX9 as a transcription factor is expected to be mainly localized in the nucleus, DAPI was used to counterstain the nuclei. The confocal analysis included all major CNS regions, including the olfactory bulb, cerebral cortex, corpus callosum, hippocampus, striatum, cerebellum, brainstem, and white and gray matter of the spinal cord (Fig. 2A). Because SOX9 has been reported to be expressed by adult neural progenitor cells and ependymal cells of the ventricular wall, we excluded the rostral migratory stream of the olfactory bulb, dentate gyrus of the hippocampus, and forebrain SVZs from our analysis.

We found that GLT1 + cell bodies were uniformly distributed in all major CNS regions examined. EGFP signal was dense in the cell body and main branches and evenly diffused in the processes, creating a light green background in GLT1-EGFP reporter mice. Most GLT1 + cells exhibited nuclear staining of SOX9 that overlap with DAPI (Fig. 2A). The proportions of SOX9+ cells among all histologically identified GLT1 + cells were as follows: olfactory bulb: $80.61 \pm 7.18 \%$; cerebral cortex: $95.04 \pm 7.82 \%$; corpus callosum: $86.25 \pm 11.36 \%$; hippocampus: $91.36 \pm 12.54 \%$; striatum: $97.22 \pm 4.81 \%$; thalamus: $92.23 \pm 7.33 \%$; cerebellum: $98.49 \pm 3.03 \%$; brainstem: $97.48 \pm 2.18 \%$; spinal cord white matter: $94.17 \pm 6.73 \%$; and spinal cord gray matter: $97.47 \pm$ $0.82 \%$ (Fig. 2 B). The proportions of GLT1 + cells in the SOX9+ pools were as follows: olfactory bulb: $97.67 \pm 4.02 \%$; cerebral cortex: $100 \pm 0 \%$; corpus callosum: $95.28 \pm 7.33 \%$; striatum: $100 \pm 0 \%$; thalamus: $98.33 \pm 2.89 \%$; cerebellum: $99.17 \pm 1.67 \%$; brainstem: $100 \pm 0 \%$; spinal cord white matter: $100 \pm 0 \%$; and spinal cord gray matter: $100 \pm 0 \%$ (Fig. $2 C$ ).

To extend this analysis to whole tissue, we next dissociated SOX9-EGFP adult mouse cortex acutely and fluorescently labeled the cells using a GLT1 antibody. Flow cytometry was used to examine the overlapping labeling of GLT1 with SOX9-EGFP. We found that $90.53 \%$ of GLT1 + cells were SOX9+ and $90.13 \%$ of SOX9+ cells were also GLT1+ (Fig. 2D). Due to cell loss during the dissociation process, this method could not be used to quantify the relative proportion of SOX9+ or GLT1+ cells among all cells, but rather served as a validation of the histological counts. Flow cytometry analysis documented the existence of a small population of SOX9+/GLT1 - cells, likely due to contamination by the subependymal zone, which includes SOX9+/ GLT - cells. Together, these data indicate that SOX9 can be used to identify the overwhelming majority of astrocytes in the adult brain. We did not further examine the phenotype of the small proportion of GLT1 +/SOX9- cells, but several studies have suggested that GLT1 may also be expressed by a small number of oligodendrocytes and neurons (Schmitt et al., 1996; Berger et al., 2005).

\section{SOX9 colocalization with glial and neuronal markers}

We first examined SOX9 colabeling with the intermediate filament GFAP, the most commonly used astrocyte marker. GFAP was only expressed by a small population of astrocytes in mouse cortex, whereas GFAP + cells were more uniformly distributed in the mouse hippocampus, as described previously (Bushong et al., 2004; Lovatt et al., 2007; Sofroniew and Vinters, 2010; Molofsky et al., 2012). However, nearly all GFAP + cells also expressed SOX9 and GLT1 in both cortex and hippocampus (Fig. 3A). We next assessed whether SOX9 expression overlapped that of the recently identified panastrocyte marker ALDH1L1 (Cahoy et al., 2008). Slices prepared from ALDH1L1-EGFP transgenic mice were immunolabeled against SOX9, followed by confocal analysis. Almost complete coincidence of SOX9+ cells with ALDH1L1+ cells was observed in the 

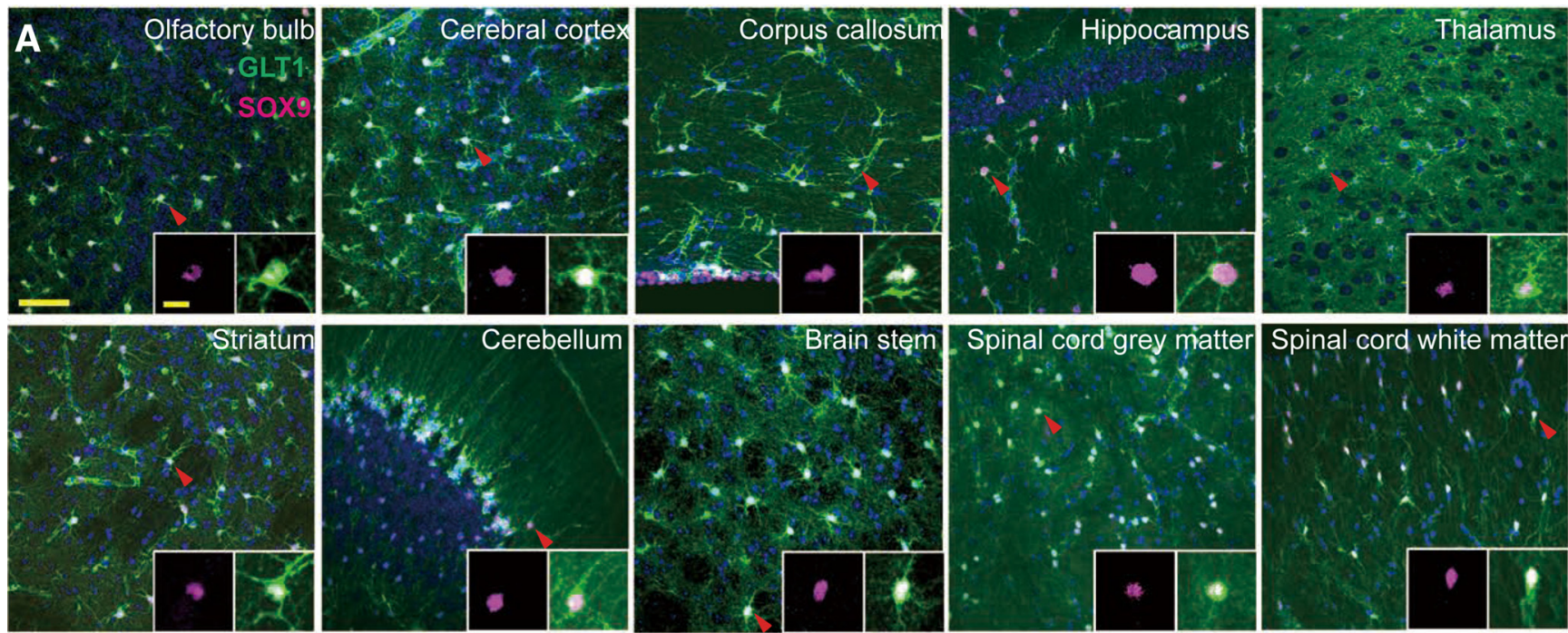

B

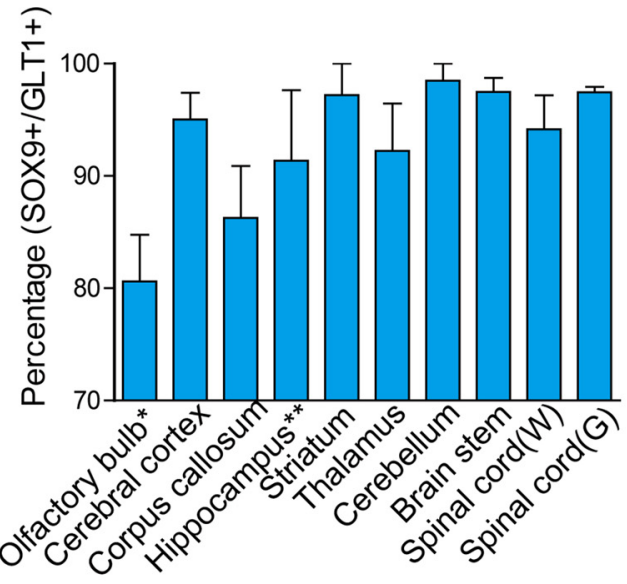

C

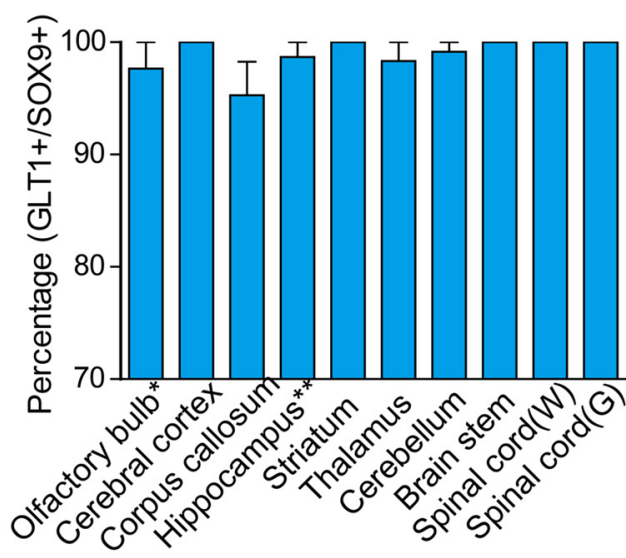

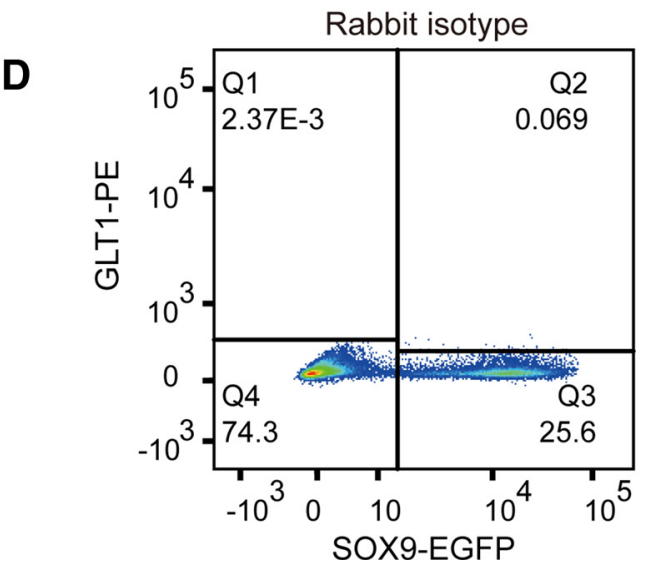

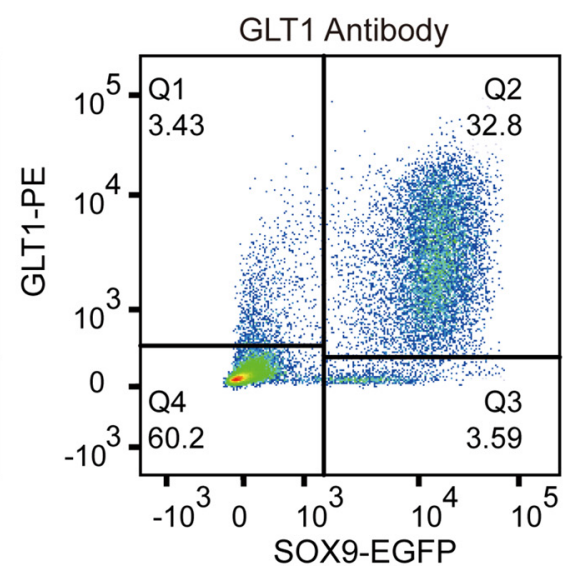

Figure 2. Overlapping of SOX9 + cells and GLT1 + cells in different brain and spinal cord regions. A, GLT1-EGFP mice were used for immunofluorescence analysis of SOX9 (purple) and GLT1 (green). DAPI (blue) was used to assist identification of brain and spinal cord regions. Overlapping of SOX 9 and GLT1 signal can be seen in white. The $10 \mu \mathrm{m}$ stack confocal images were acquired at $1 \mu \mathrm{m}$ steps. Representative images from olfactory bulb, cerebral cortex, corpus callosum, hippocampus, thalamus, striatum, cerebellum, brainstem, spinal cord white matter, and gray matter are shown. A typical cell (arrowhead) is shown in the insert of each image. B, Percentages ( $y$-axis) of S0X9 and GLT1 double-positive cells within total GLT1+ cell population were quantified manually for each region. $C$, Percentages of double-positive cells within total SOX9+ cell population were also quantified using the same method. For both $\boldsymbol{B}$ and $\boldsymbol{C}$, data were collected from three mice with at least three images/mouse under a $40 \times$ objective lens for each region. Error bar indicates SD. ${ }^{*}$ Rostral migratory stream was excluded for the quantification of the olfactory bulb. ${ }^{* *}$ Dentate gyrus was excluded from the quantification of the hippocampus. Major scale bar, $50 \mu \mathrm{m}$; insert scale bar, $5 \mu \mathrm{m}$. $\boldsymbol{D}$, Flow cytometry analysis of acutely dissociated cells from adult murine cortical tissue. Sox9-EGFP mice were used for dissociation. EGFP was used to identify SOX9+ cells and GLT1 antibody labeling (with PE-labeled secondary antibody) was used to identify GLT1 + cells. The plot on the left is a representative analysis for isotype antibody control. The plot on the right is a representative analysis for GLT1 and EGFP double labeling. 

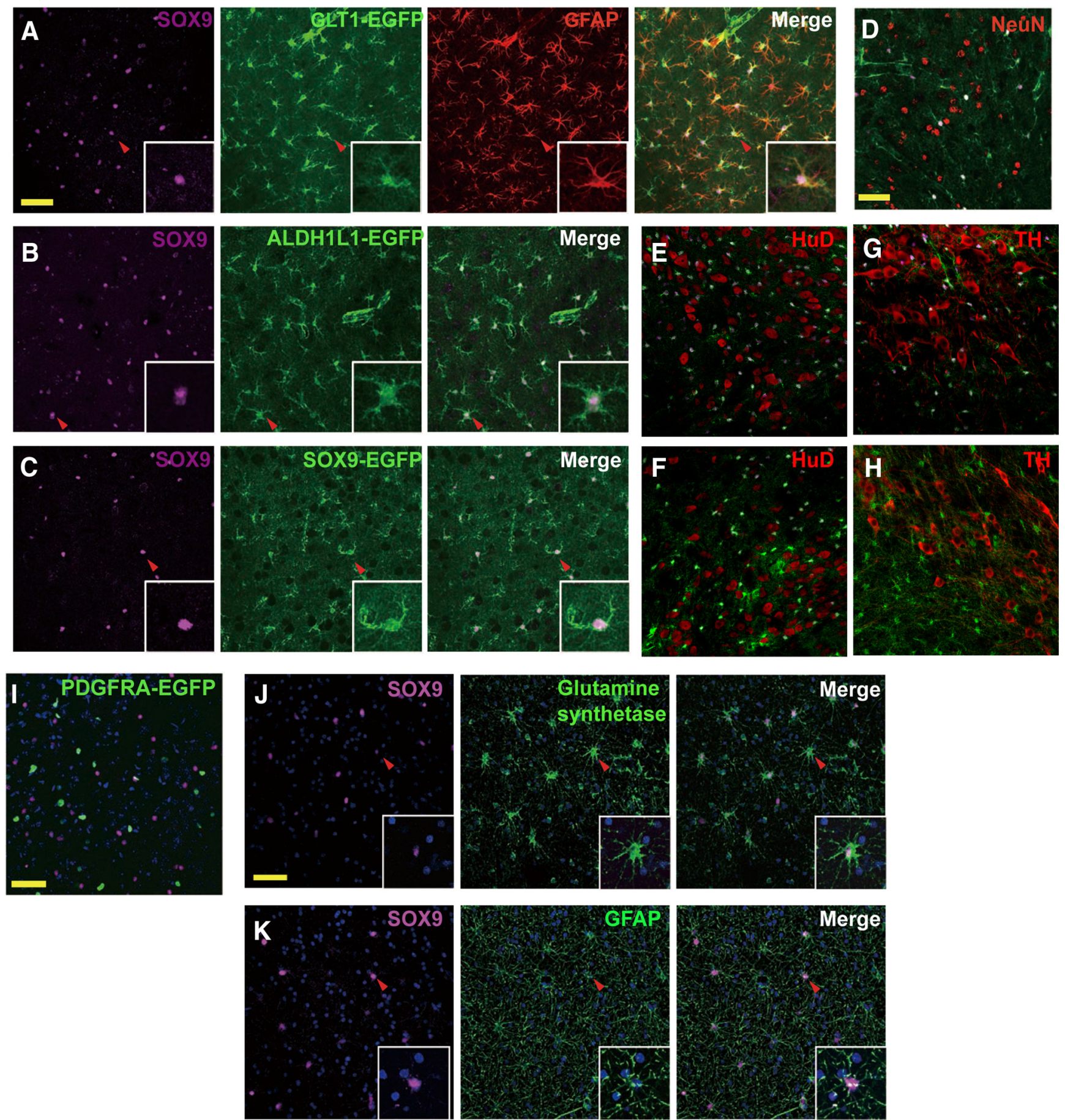

Figure 3. Colabeling of $S 0 X 9$ with astrocyte markers. $A$, Immunofluorescence analysis of $S 0 X 9$ colabeling with the astrocyte marker GFAP in the mouse cerebral cortex. Cortical sections from GLT1-EGFP (green) mice were immunolabeled against SOX9 (purple) and GFAP (red). SOX9 + cells also express GLT1 and GFAP. B, Immunofluorescence analysis of SOX9 colabeling with astrocyte marker ALDH1L1 in the mouse cerebral cortex. ALDH1L1-EGFP mice were used to visualize ALDH1L1+ astrocytes (green) and were immunostained against SOX9 (purple). Representative confocal images show that S0X9 + cells also express ALDH1L1. C, Total overlapping between SOX9-EGFP and S0X9 antibody labeling. Sections from SOX9-EGFP (green) mice were immunolabeled against SOX9 (purple). Representative images from the cerebral cortex are shown. $\boldsymbol{D}$, Sections prepared from GLT1-EGFP (green) mice were immunolabled against NeuN (red) and SOX9 (purple). A representative image from the mouse cortex is shown. There is no overlap between SOX9+ and NeuN + cells. $\boldsymbol{E}, \boldsymbol{F}$, Immuostaining of mouse locus ceruleus $(\boldsymbol{E})$ and substantia nigra pars compacta $(\boldsymbol{F})$ of neuronal marker HuD (red) and S0X9 (purple) on S0X9-EGFP (green) mice. $\boldsymbol{G}, \boldsymbol{H}$, Immunostaining of mouse locus ceruleus ( $\boldsymbol{G}$ ) and substantia nigra pars compacta $(\boldsymbol{H})$ with TH (red) and SOX9 (purple) on S0X9-EGFP (green) mice. $\boldsymbol{I}$, Sections prepared from PDGFRA-EGFP (green) mice were immunolabeled against SOX9 (purple). DAPI was used to stain the nuclei. A representative image from the cortex shows that no cell is colabeled with PDGFRA and SOX9. J, $\boldsymbol{K}$, SOX9 expression in the human brain. $J$, Human cortical sections were immunostained against SOX9 (purple) and GS (green). GS is shown to be expressed by astrocytes (star pattern) and oligodendrocytes (circular pattern). Star-shaped GS + cells are positive for S0X9, whereas round-shaped GS + cells are not. $\boldsymbol{K}$, Confocal imaging of human cortical tissue immunolabeled against S0X9 (purple) and the astrocyte marker GFAP (green). SOX9 + cells also express GFAP. Representative views of single cells are shown in the inserts. Scale bar, $50 \mu \mathrm{m}$. Confocal images were collected at $10 \mu \mathrm{m}$ depth using $1 \mu \mathrm{m}$ steps. 

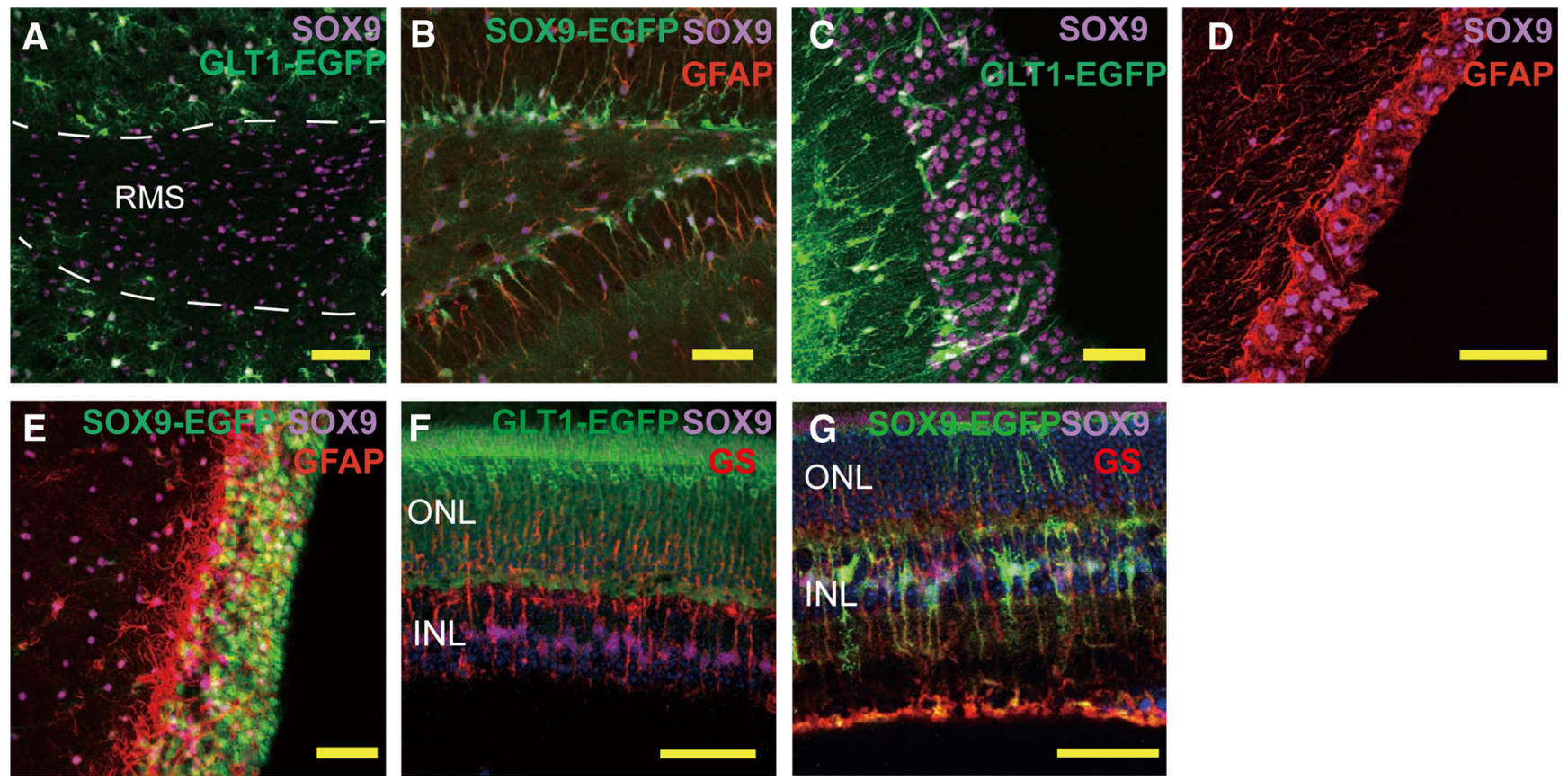

Figure 4. SOX9 is expressed in the adult neurogenesis region and in the retina. $A$, Sections of the olfactory bulb from GLT1-EGFP mice were immunolabeled against SOX9. Confocal images of the rostral migratory stream showed a lack of GLT1 (green) signal in the rostral migratory stream, whereas SOX9+ cells (purple) are densely distributed. $\boldsymbol{B}$, In the dentate gyrus, S0X9-EGFP + (antibody, purple; EGFP, green) cells are shown in the subgranular cell layer with their processes extending to the granular cell layer. Those cells also express GFAP (red). C, In GLT1-EGFP (green) mouse, SOX9 (purple) is highly expressed in the subventribular zone. Only a small portion of SOX9+ cells in the SVZ express GLT1. Scale bar, $50 \mu \mathrm{m}$. D, In the subventricular region, SOX9+ (purple) nuclei are surrounded by GFAP (red) expression. $E$, In SOX9-EGFP mouse, the majority of the cells in the subventricular region express EGFP (green). EGFP + cells are also positive for SOX9 antibody labeling (purple) and are surrounded by GFAP+ fibers (red). $\boldsymbol{F}$, In the GLT1-EGFP mouse, on the retina, SOX9 + cells (purple) are also positive for Müller glia marker GS (red). GLT1 does not label Müller glia. G, SOX9 expression in the retinal glial cells. ONL, Outer nuclear layer; INL, inner nuclear layer. Retina sections from SOX9-EGFP (green) mice were fluorescently labeled against SOX9 (purple) and GS (red) antibodies. Müller glia express both SOX9 (purple and red) and GS. Scale bar, $50 \mu \mathrm{m}$.

cortex (Fig. 3B). To verify that double labeling of SOX9 with GLT1, GFAP, and ALDH1L1 was not an artifact, we also prepared sections from SOX9-EGFP reporter mice (Gong et al., 2003). Again, an almost complete overlap of SOX9 immunoreactivity and EGFP signal was noted in the cerebral cortex (Fig. 3C).

During embryonic development, SOX9 is expressed by neural stem cells and plays a key role in the specification of glial lineage, which includes both astrocytes and oligodendrocytes (Stolt et al., 2003). We further investigated whether SOX9 labels neurons or OPCs in the adult mouse brain. Cortical sections prepared from GLT1-EGFP mice were immunostained against SOX9 and neuronspecific nuclear protein (NeuN). No colocalization of SOX9 and NeuN was observed in the mouse cortex (Fig. 3D). In addition, we examined the mouse locus ceruleus and substantia nigra pars compacta using SOX9 co-staining with the alternative neuronal nuclear marker $\mathrm{HuD}$, as well as the dopaminergic and adrenergic neuronal marker tyrosine hydroxylase (TH), in SOX9-EGFP reporter mice. We found no overlapping of SOX9 with either HuD or TH. For identification of OPCs, a transgenic mouse carrying a human $\mathrm{H} 2 \mathrm{~B}$ histone protein and EGFP fusion gene under the control of Pdgfra promotor (PDGFRA-EGFP) was used. In this mouse strain, OPCs have EGFP signaling only in the nuclei, which makes it easy to visualize colocalization with SOX9, which also labels nuclei. However, in the adult cortex (Fig. 3E), no colocalization of PDGFRA and SOX9 signal was observed. These observations are consistent with previous reports that SOX9 expression is lost in oligodendrocyte progenitor cells (Stolt et al., 2003). In summary, our study demonstrated that, outside of the adult neurogenic regions, SOX9 is expressed exclusively in astrocytes and SOX9, GLT1, and ALDH1L1 effectively colabel the same population of astrocytes.

\section{SOX9 expression by human astrocytes}

We next assessed whether SOX9 is also expressed selectively by astrocytes in the human brain. Human cortical samples collected during surgery were immunostained for GFAP, SOX9, and glutamine synthetase (GS), which label the astrocyte cell bodies and major processes. The analysis showed that GS + cells exhibit two kinds of morphology: circular and star shaped. The star-shaped GS + cells with multiple branches are considered to be astrocytes, whereas the circular-shaped GS + cells are considered other cell types. Although the expression of GS in cells other than astrocytes has been controversial, a recent detailed study of GS expression in human brain found that subpopulations of oligodendrocytes, neurons, and microglia may all express GS (Bernstein et al., 2014; Zhang et al., 2016). We found that all GS + astrocytes coexpressed SOX9 (Fig. 3F). SOX9+ astrocytes also expressed GFAP (Fig. $3 G)$. Combined, these findings suggest that SOX9 is expressed by $\mathrm{GS}+$ and GFAP + human cortical astrocytes.

\section{SOX9 expression in the neurogenic regions}

According to previous reports, SOX9 is expressed by ependymal cells and subependymal cells (Scott et al., 2010). We therefore examined the adult neurogenic regions, including the RMS of the olfactory bulb, SGZ of the hippocampus, and SVZ. GLT1-EGFP mouse olfactory bulb was immunostained against SOX9. In contrast to the loose, even distribution of SOX9+ astrocytes in the non-neurogenic region of the olfactory bulb, SOX9+ cells are densely packed in the RMS. The RMS can easily be identified by the lack of GLT1 and dense confluence of SOX9+ cells (Fig. 4A). In the dentate gyrus of the hippocampus, SOX9+ cells can similarly be observed in the SGZ, where they also express GFAP. 


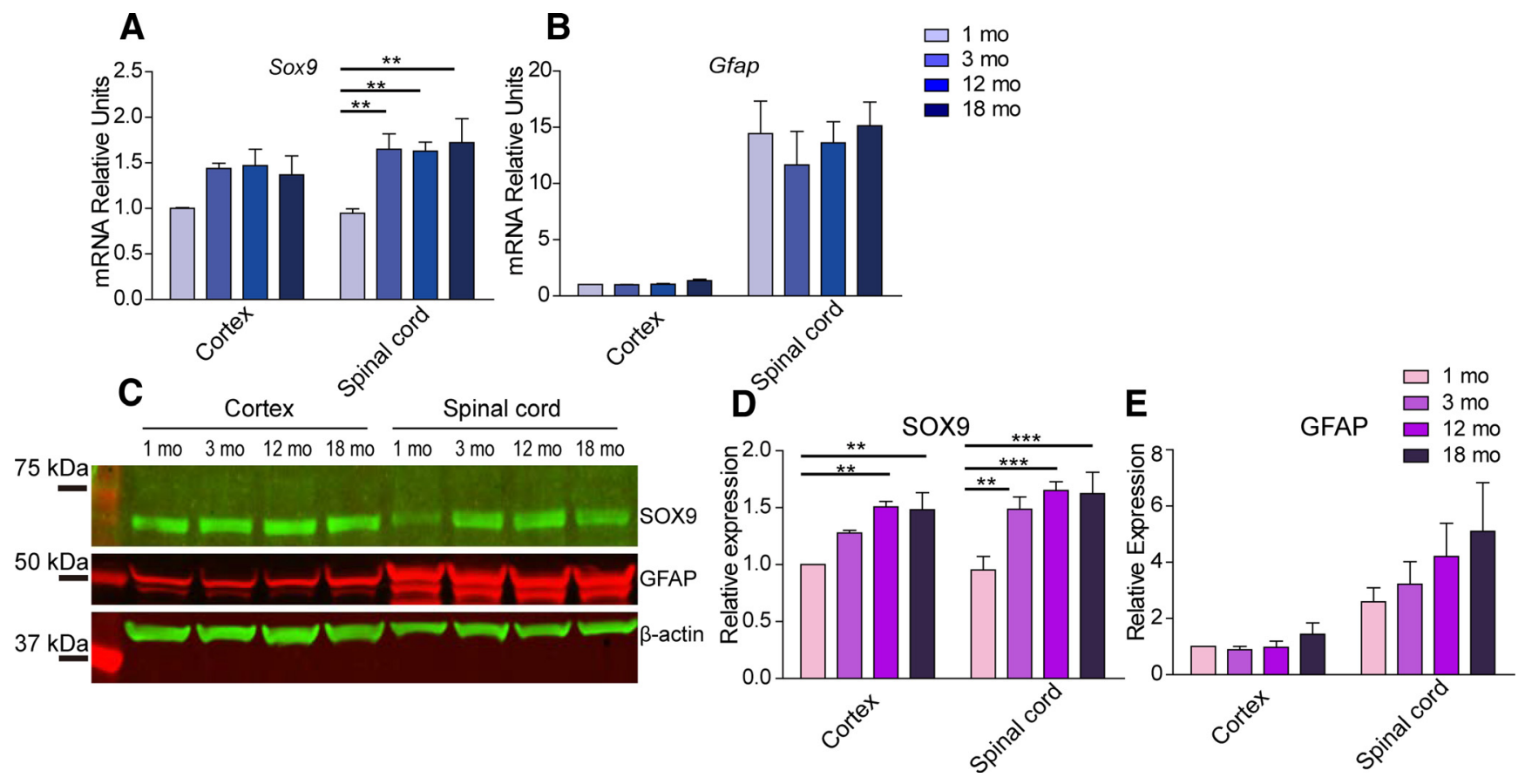

Figure 5. Age-related changes of SOX9 and GFAP expression in the brain and spinal cord. $A, B$, mRNA expression of Sox 9 and Gfap in the mouse cortex and spinal cord tissue was examined at 1 , 3, 12, and 18 months of age using qPCR. Relative expression values were calculated using Gapdh as an internal control. C, Western blot analysis showing protein expression levels at 1, 3, 12, and 18 months of age. $D, E$, Quantification of Western blotting showed age-related changes of SOX9 and GFAP protein expression. Statistical analysis was done using two-way ANOVA followed by Bonferroni posttests. $n=3$ mice; ${ }^{* *} p<0.01 ; * * * p<0.001$. Error bar indicates SD.

Immunolabeling of slices prepared from SOX9-EGFP mouse for GFAP shows that SOX9+ nuclei in the SGZ have long GFAP+/ $\mathrm{EGFP}+$ processes extending into the granular cell layer, a characteristic feature of SGZ neural stem cells (Fig. 4B) (Filippov et al., 2003; Kronenberg et al., 2003). On that basis, we next assessed SOX9 expression in the SVZ, which is another major site of adult neurogenesis in rodents. In GLT1-EGFP mice, only a few GLT1+ cells were scattered in the SVZ, but a thick layer of densely packed SOX9+ cells could be observed (Fig. 4C). Costaining of GFAP and $\mathrm{SOX} 9$ showed that these $\mathrm{SOX} 9+$ nuclei were enwrapped by GFAP fibers (Fig. 4D). Using SOX9-EGFP mice, we found that EGFP + cells overlapped SOX9+ cells and were also surrounded by GFAP fibers (Fig. 4E). Together, these results demonstrated that SOX9 is expressed by cells in the adult murine SVZ, olfactory bulb, RMS, and hippocampal SGZ in a distribution that suggests its colocalization with neural stem and/or transit-amplifying progenitor cells (Alvarez-Buylla and Temple, 1998; Horner and Gage, 2000; Goldman and Sim, 2005), consistent with a previous suggestion that SOX9 participates in neurogenesis in the adult SVZ (Cheng et al., 2009).

\section{SOX9 expression on the retina}

SOX9 has also been reported to be expressed by retinal astrocytes and Müller glial cells (Fischer et al., 2010). Analysis of retinal slices prepared from GLT1-EGFP mice shows that GLT1 and SOX9 signals do not overlap. GLT1 is expressed by a population of cells in the outer nuclear layer, whereas SOX9 is most prominent in the inner nuclear layer. Additional analysis using GS immunolabeling showed that SOX9 + cells in the inner nuclear layer coexpressed GS, which was histologically confirmed as Müller glial cells, as described previously (Fischer et al., 2010) (Fig. 4F). This conclusion was independently verified by immunostaining for GS on retinal slices prepared from SOX9-EGFP transgenic mice, in which the EGFP signal consistently overlapped with those of GS and SOX9 (Fig. 4G).

Age-related changes of SOX9 expression in mouse cortex and spinal cord

Age-related changes of SOX9 and GFAP expression were examined in the same samples. Wild-type 1-, 3-, 12-, and 18-monthold mice were perfused with PBS and their cortices and spinal cords were harvested for RNA and protein preparation. qPCR analysis showed no significant changes in Sox9 mRNA expression in animals from 3 to 18 month of age in either the cortex or the spinal cord. However, Sox9 expression was significantly lower at 1 month of age compared with 3,12 , and 18 months of age in the spinal cord. Similarly, in the cortex, there was a nonsignificant trend toward a lower Sox9 mRNA expression at 1 month of age compared with older age groups (Fig. 5A). Western blotting showed that SOX9 protein increased with age in spinal cord samples; in the cortex, its expression similarly increased with age in the 12- and 18-month-old samples (Fig. 5C,D). Interestingly, both Western blotting and qPCR demonstrated that cortical expression of GFAP was dramatically less than that of the spinal cord at all ages (Fig. $5 B, C, E$ ). Together, these results suggest that the relative SOX9 expression increases from 1 to 3 months of age, likely congruent with the postnatal addition of astrocytes, whereas its expression level remained relatively stable with subsequent aging.

\section{SOX9 expression in reactive astrocytes}

Astrocytes responded to both acute injury and chronic neurodegenerative diseases by increasing their expression of GFAP (Yang and Wang, 2015) and their rate of proliferation (Bardehle et al., 2013). Reactive astrocytes lose their domain organization and their numbers are difficult to quantify due to the often extensive 
intermingling of their strongly labeled GFAP + processes (Oberheim et al., 2008). A nuclear marker would therefore be a helpful tool to study astrocytes in tissue with reactive astrogliosis. In a mouse model of ALS (SOD1G93A), we found that SOX9 was dramatically upregulated at the symptomatic stage in the spinal cord, along with GFAP (Fig. 6A,B). Further validation based on Western blotting confirmed the upregulation of both GFAP and SOX9 compared with aged-matched littermates (Fig. 6C,D). In addition, SOX9 upregulation were also observed in reactive astrocytes in the penumbral cortical regions after MCAO and after multiple ministrokes (Fig. 6E,F). GFAP expression can be observed in most SOX9+ reactive astrocytes in the spinal cord in SOD1G93A mice. In the cerebral cortex of MCAO mouse model, we did observe a few SOX9+ cells that were GFAP-, but almost all of these cells expressed another astrocyte marker, $S 100 \beta$ (Fig. $6 E$ ). This observation is consistent with previous reports showing that a significant number of $S 100 \beta+/ \mathrm{GFAP}-$ astrocytes are present even in pathological states (Walz and Lang, 1998; Wang and Walz, 2003; Ruscher et al., 2009; Sirko et al., 2015).

\section{RNA-seq comparing the transcriptome of SOX9+ and GLT1+ cells}

GLT1-EGFP and ALDH1L1-EGFP reporter mice are useful for isolating astrocytes (Doyle et al., 2008; Heiman et al., 2008; Yang et al., 2011). We next investigated whether SOX9-EGFP mice also can be used to isolate astrocytes and, if so, whether the transcriptomes of GLT1+ and SOX9+ cells are comparable. Cortical tissues were dissociated from both mouse strains and then astrocytes (GLT1 + cells or SOX9 + cells) and astrocyte-depleted cells (GLT1 - or SOX9- cells) were collected for RNA-seq analyses. A total of 20,118 genes were detected in at least one cell type. First, we looked at the sample-to-sample distance matrix and unsupervised hierarchical clustering of all detected genes for each sample (Fig. 7A). We found that the gene expression profiles of SOX9+ cells and GLT1 + cells were very similar to each other and SOX9cells and GLT1 - cells were also very similar; in contrast, astrocytes (GLT1+ or SOX9+) and astrocyte-depleted cells (GLT1- or SOX9-) were much further away from each other. We further looked at the unsupervised clustering of samples based on the top 250 most variable genes determined by the coefficient of variation of each gene. Similarly, SOX9+ cells and GLT1+ cells clustered together, whereas SOX9- cells and GLT1- cells were clustered separately (Fig. 7C).

These data indicate that the variability between these groups was determined primarily by the difference in cell types, not by the markers used to purify them (GLT1 or SOX9). To further look at the gene expression profile similarity between SOX9+ cells and GLT1 + cells, $\log 2$-transformed gene expression values for all SOX9+ cells and GLT1 + cells were plotted against each other. We found that the two samples are highly similar in terms of gene expression with a Spearman correlation coefficient of 0.97 and Pearson correlation coefficient of 0.92 (Fig. $7 B$ ). Finally, we examined cell marker expression by the four cell populations. We looked at multiple markers for astrocytes, microglia, endothelial cells, mural cells (pericytes and smooth muscle cells), myelinating oligodendrocytes, oligodendrocyte progenitor cells, and neurons. We found that SOX9+ cells and GLT1+ cells (and also SOX9- cells and GLT1 - cells) are almost identical in marker gene expression levels. Both SOX9+ cells and GLT1+ cells are high in astrocyte marker expression and low in the expression of markers for other cell types (Fig. 7D). Based on these findings, we conclude that the mRNA profiles of SOX9+ cells reflect astrocytic gene expression.

\section{Quantification of astrocytes using the isotropic fractionator method}

As noted above, ALDH1L1, GLT1, and SOX9 colabeled most astrocytes. However, we noted that ALDH1L1+, GLT1+, and $\mathrm{SOX} 9+$ cells did not as a group comprise the majority of all cells, calling into question the common notion that astrocytes are the most abundant cell type in the CNS (Kandel et al., 2000; Nedergaard et al., 2003; Hilgetag and Barbas, 2009). Recent studies using a method called "isotropic fractionator" in combination with NeuN immunolabeling suggested that the neuron-to-glia ratio (glia in this case a misnomer, including all non-neuronal cells, such as astrocytes, oligodendrocytes, OPCs, microglia, endothelial cells, and pericytes) is $\sim 1: 1$ and, furthermore, that $\sim 80 \%$ of all neurons in the CNS reside in the cerebellum, including in humans, nonhuman primates, and rats (HerculanoHouzel and Lent, 2005; Azevedo et al., 2009). Although these reports were initially considered controversial, subsequent work validated this methodology using stereology (Bahney and von Bartheld, 2014). Briefly, the isotropic fractionator technique converts brain tissue into a homogenous nuclear suspension and the nuclei are labeled with DAPI and counted manually using a hemocytometer. Neurons are identified by immunostaining of the nuclei against NeuN. Combining isotropic fractionator with flow cytometry (also called "flow fractionator") has been shown to be more accurate and efficient for cell quantification (Collins et al., 2010).

On that basis, we took advantage of $\mathrm{SOX} 9$ as the first identified astrocyte nuclear antigen to assess their relative percentage using the flow fractionator technique. We examined the proportion of astrocytes in the olfactory bulb, neocortex, hippocampus, cerebellum, and spinal cord in adult mice. We prepared single nuclei suspension and identified DAPI+ single nuclei using flow cytometry (Fig. 8A,B). NeuN and SOX9 were then fluorescently immunolabeled and analyzed separately to avoid antibody crossreaction. We found that the relative percentages of NeuN + cells among all DAPI + cells were as follows: olfactory bulb: $57.6 \pm$ 0.7\%; neocortex: $25.48 \pm 1.65 \%$; hippocampus: $26.05 \pm 3.18 \%$; cerebellum: $76.28 \pm 5.43 \%$; the rest of the brain (with the abovementioned structures removed): $28.59 \pm 3.35 \%$; and spinal cord: $13.68 \pm 2.09 \%$. These numbers are consistent with those noted in a recent study of the mouse brain using isotropic fractionator $(\mathrm{Fu}$ et al., 2015) (Fig. 8C,D). For SOX9+ cells, the proportions among all DAPI + cells were as follows: olfactory bulb: $3.22 \pm$ $0.48 \%$; neocortex: $13.7 \pm 1.30 \%$; hippocampus: $15.89 \pm 2.49 \%$; cerebellum: $3.7 \pm 0.51 \%$; the rest of the brain: $13.1 \pm 2.15 \%$; and spinal cord: $13.2 \pm 1.87 \%$ (Fig. $8 E, F$ ). The nuclei not labeled by either SOX9 or NeuN were composed of a mixture of nuclei from the oligodendrocyte lineage cells, microglial cells, smooth muscle cells, and endothelial cells based on previous reports (Pelvig et al., 2008; Zeisel et al., 2015). The percentages of NeuN-defined neurons were much higher in the olfactory bulb and cerebellum, in which densely packed granule neurons predominate and in which astrocytes are relatively scarce. Interestingly, our analyses suggest that neocortex, hippocampus, and the rest of the brain contain approximately similar proportions of neurons and astrocytes. The spinal cord contains similar proportions of astrocytes as the neocortex, but its relative proportion of neurons is lower, likely reflecting the large number of oligodendrocytes in its ascending and descending tracts. Overall, this analysis shows that astrocytes constitute between $\sim 10 \%$ and $20 \%$ of all cells in the CNS, except in the cerebellum and olfactory bulb, where only $\sim 3-5 \%$ of cells are astrocytes. 

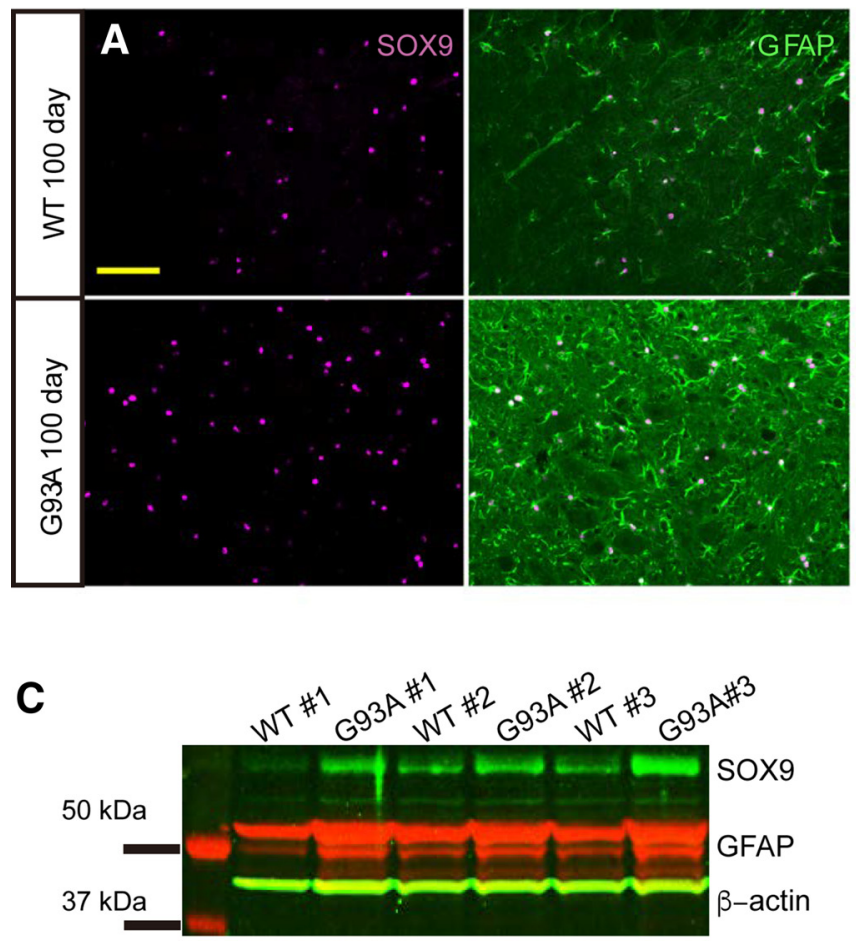

D
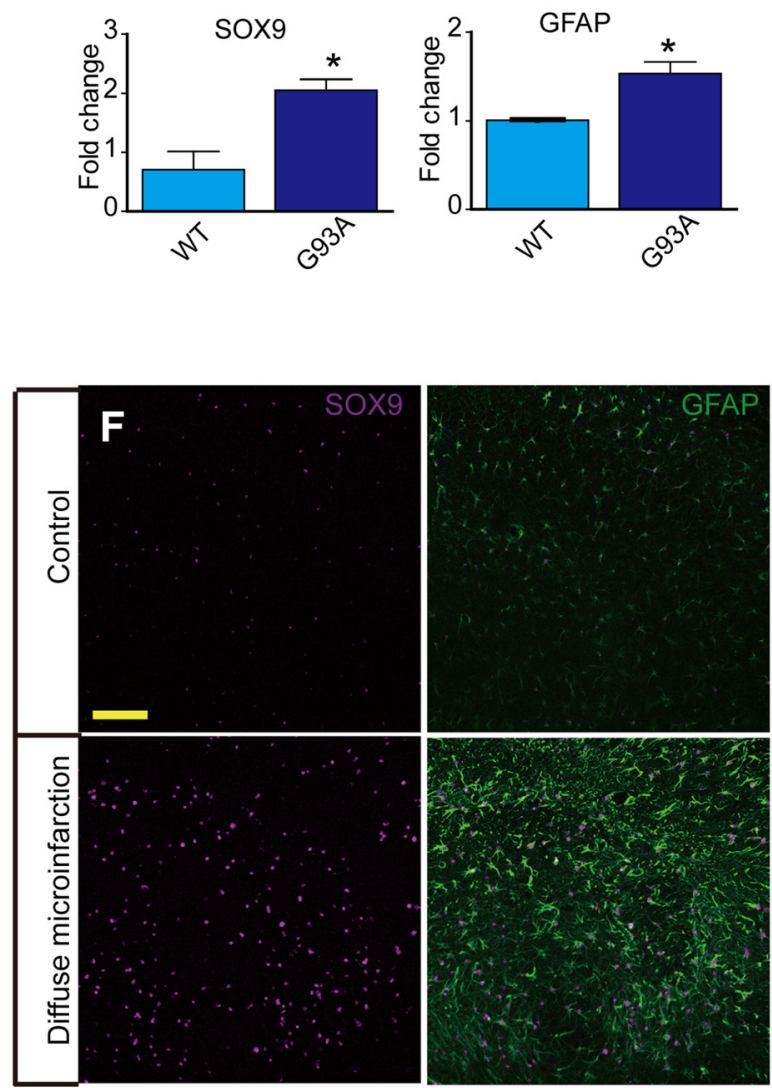

B
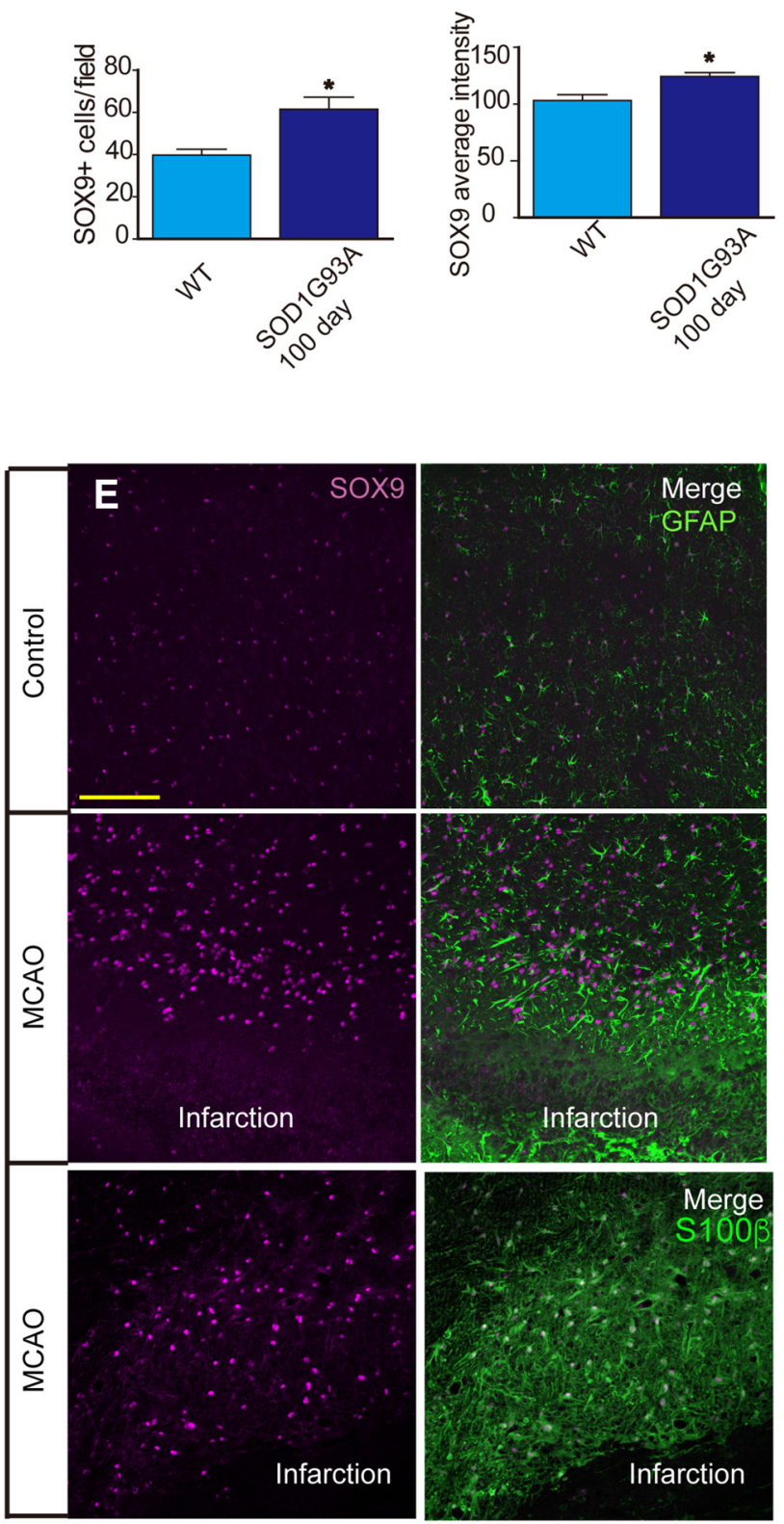

Figure 6. SOX9 is upregulated in reactive astrocytes. A, Spinal cord sections from 100-d-old wild-type (WT) littermates and SOD1G93A mice were immunostained against SOX9 (purple) and GFAP (green). Both SOX9 and GFAP are strongly upregulated in the ventral horn of the SOD1G93A mice compared with WT littermates. B, Quantification of the images produced in $A$ showing that both the number of SOX9+ cells and SOX9 expression intensity per cell, are significantly increased. $n=3$ mice; ${ }^{*} p<0.05$. Error bar indicates SD. C, Western blotting using antibodies against SOX9 (green) and GFAP (red). Beta-actin was used as an input control. D, Quantification of C showing that both SOX9 and GFAP are upregulated in the spinal cords of SOD1G93A mice at the symptomatic stage compared with WT littermates. $n=3$ mice. ${ }^{*} p<0.05$. Error bar indicates SD. E, Two weeks after MCAO, brain sections were immunostained against either SOX9 (purple) and GFAP (green) or SOX9 (purple) and $\mathrm{S} 100 \beta$ (green). Sections from noninjured brain were used as controls. $\boldsymbol{F}$, Two weeks after diffuse infarction, sections from hippocampus were immunostained against $S 0 \mathrm{X} 9$ (purple) and GFAP (green). Sections from a noninjured brain were used as controls. 

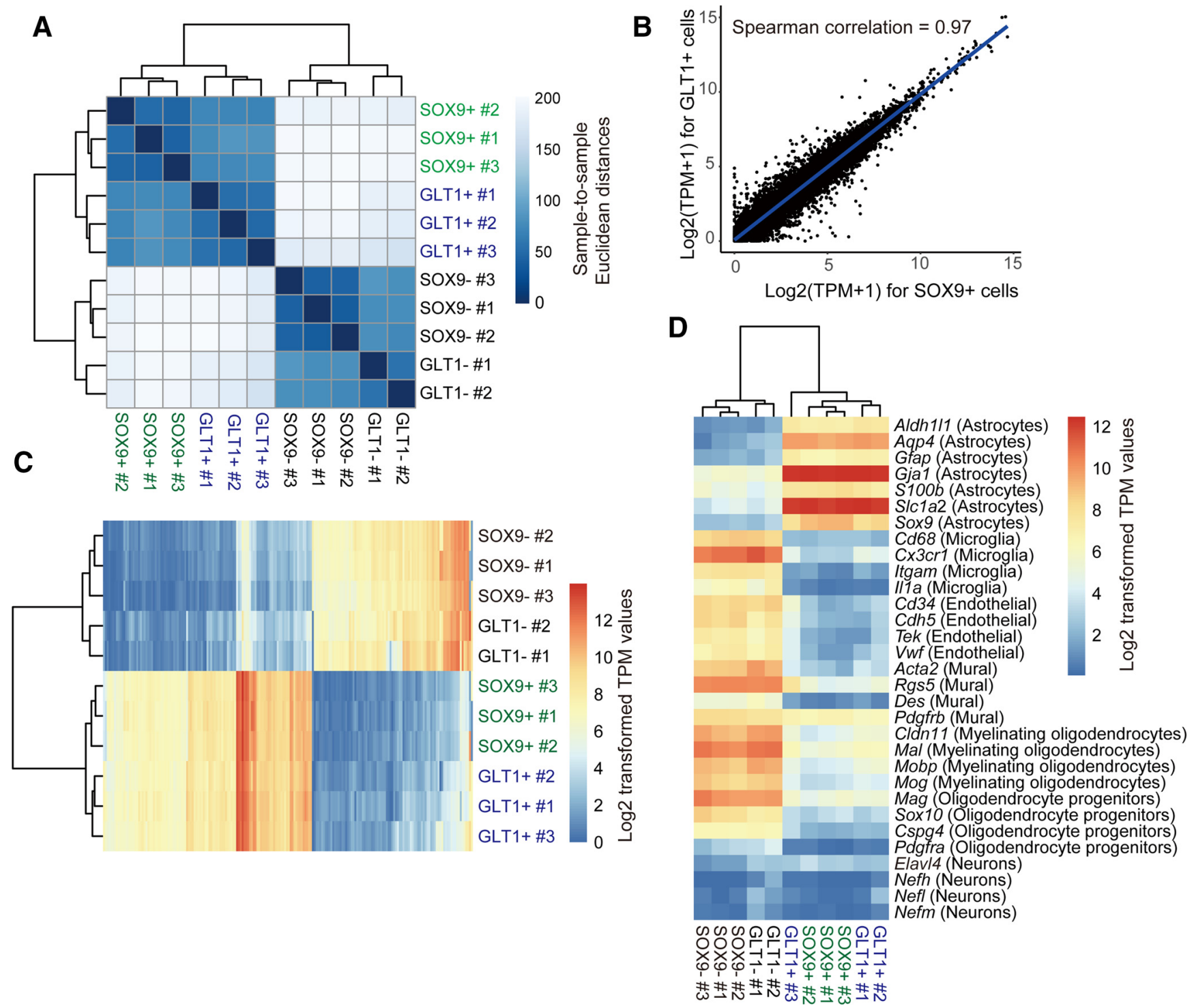

Figure 7. Comparison of RNA transcriptome profiles between S0X9+ and GLT1+ cells. A, Relationship of transcriptome profiles among GLT1+, S0X9+, GLT1-, and S0X9- samples. Sample-to-sample Euclidean distance matrix with hierarchical clustering using rlog-transformed read counts of 20,118 detected transcripts. $\boldsymbol{B}$, Scatter plot of log 2 average transformed TPM values from S0X9+ cells and GLT1 + cells. Spearman correlation coefficient is calculated and shown on the plot. C, Unsupervised hierarchical clustering of samples and heat map based on log2transformed TPM values of the top 250 variably expressed genes. D, Unsupervised hierarchical clustering of samples and heat map showing log2-transformed TPM values of marker genes for different cell types.

\section{Discussion}

In this study, we showed that both SOX9 mRNA and protein are expressed almost exclusively by astrocytes in the adult murine brain, including its expression by a population of glial lineage cells (Doetsch et al., 1999), within the subependymal and subgranular neurogenic regions. Previous transcriptome analyses of astrocytic genes have suggested that SOX9 is expressed specifically by astrocytes (Lovatt et al., 2007; Zhang et al., 2014; Farmer et al., 2016; Zhang et al., 2016). However, detailed examination of colabeling of SOX9 with other astrocyte markers in multiple CNS regions, as well as at different ages and pathologies, is required to validate SOX9 as an astrocyte-specific marker. For example, GLT1 has been used widely to identify astrocytes due to its strong expression and specificity in astrocytes, as well as its broader coverage of astrocytes than GFAP (Lovatt et al., 2007). However, GLT1 is regulated developmentally and may be modulated functionally; for example, in reactive gliosis, GLT1 is downregulated significantly (Dunlop et al., 2003; van Landeghem et al., 2006), limiting its use in disease. GFAP is the most commonly used astrocyte marker, but it only labels a small portion of astrocytes in the normal mouse cortex (Wang and Walz, 2003; Sofroniew and Vinters, 2010; Molofsky et al., 2012). In addition, $S 100 \beta$ has been shown to label astrocytes, but it is also expressed by oligodendrocytes and their progenitors (Steiner et al., 2007). This study is the first, to our knowledge, to establish that SOX9 may be used as an astrocyte-specific nuclear marker both across ages and throughout the CNS. This study is also the first to demonstrate that GLT1, SOX9, and ALDH1L1 are largely coexpressed by the same population of cells and these three markers identify the vast population of astrocytes in adult mouse brain. Moreover, whereas all three may serve as pan-astrocyte markers, GLT1 and ALDH1L1 are distributed evenly across the cell bodies and processes of astrocytes, whereas $\mathrm{SOX} 9$ is primarily localized in the nucleus. Identification of astrocytes by such a nuclear marker may provide 

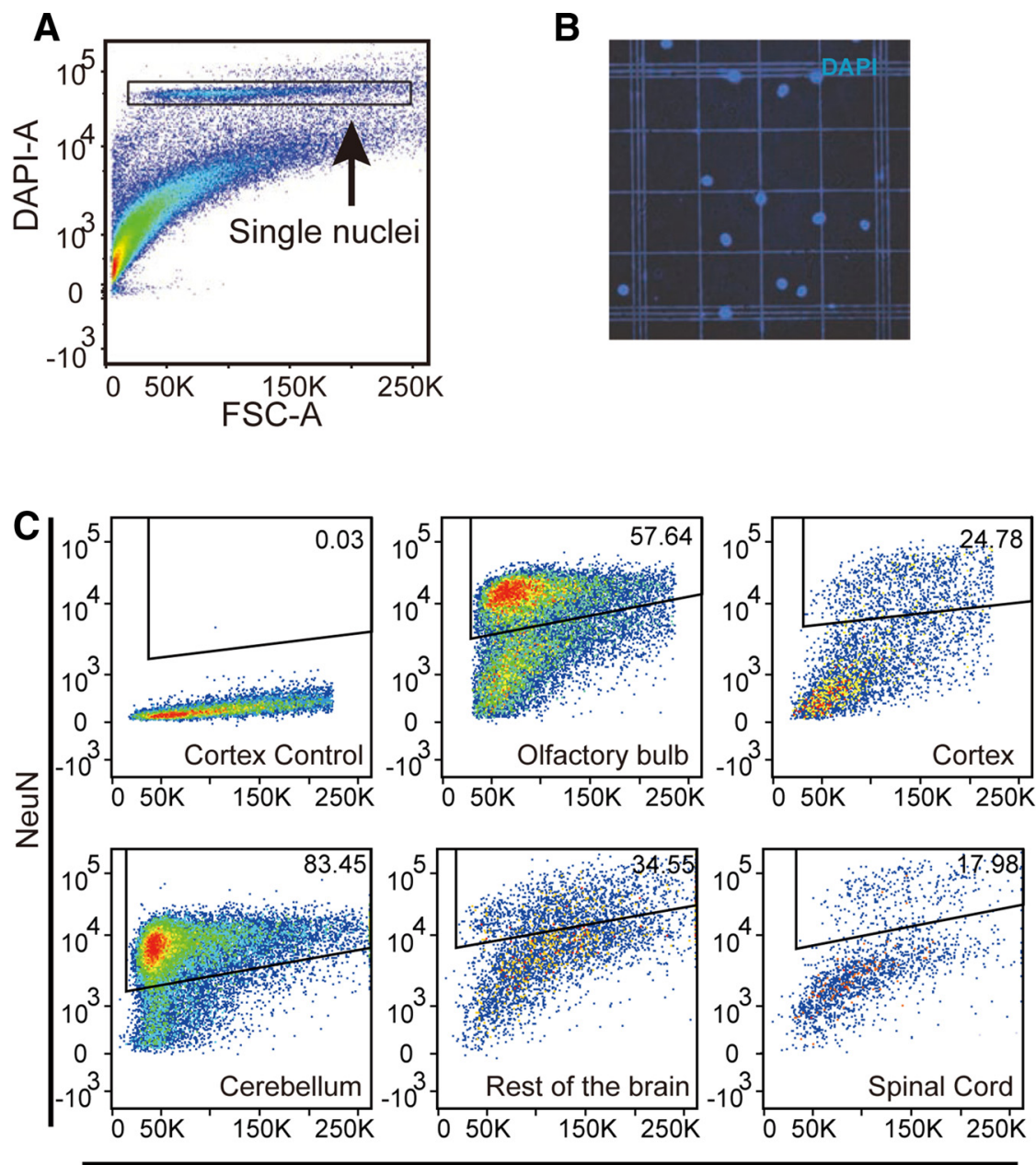

FSC-A
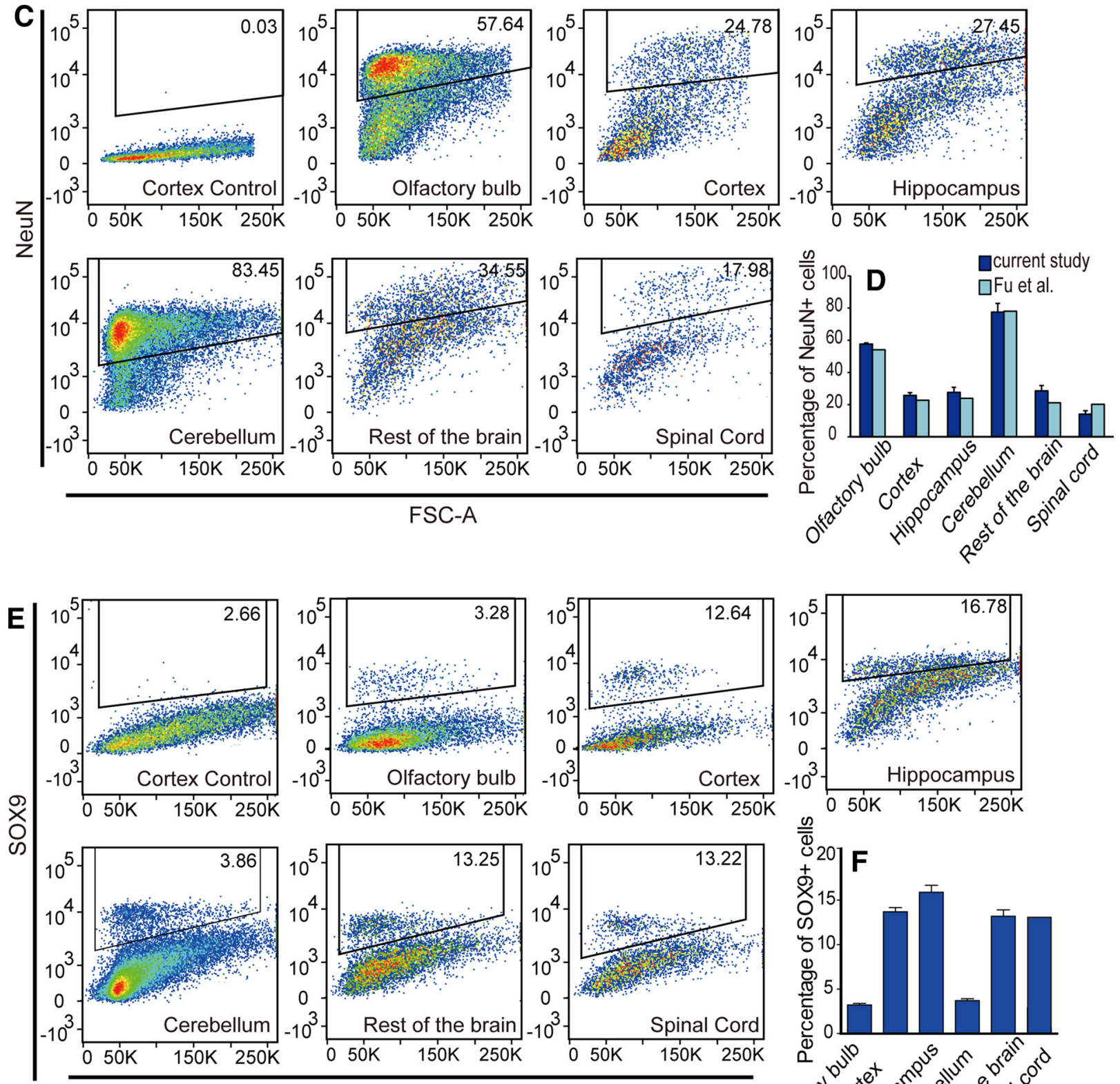

FSC-A

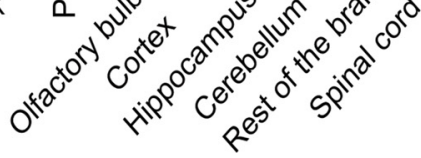

Figure 8. Quantification of the proportions of neurons and astrocytes using isotropic fractionator and flow cytometry. $A$, Single nuclei suspensions were prepared from the brain tissue and labeled with DAPI. Flow cytometry was used for the identification of single nuclei. Fluorescence of DAPI (DAPI-A) is plotted against forward scatter (FSC-A). The DAPI+ population containing single nuclei was gated for further analysis. B, Representative view of DAPI-labeled single nuclei preparation. C, Proportions of NeuN + cells in the olfactory bulb, cortex, hippocampus, cerebellum, spinal cord, and the rest of the brain. Fluorescence staining of NeuN was plotted against FSA. The first plot is a representative isotype control staining for the cerebral cortex. For each (Figure legend continues.) 
significant advantage in histological analysis, especially under conditions in which astrocytes have lost their domain organization. We found that SOX9 expression did not change with aging, but was upregulated in reactive astrocytes in mouse models of ALS and stroke, just as prior studies have shown that SOX9 is upregulated after spinal cord injury (Barnabé-Heider et al., 2010; McKillop et al., 2013; McKillop et al., 2016). In no case was SOX9 lost to histological detection. Although most $\mathrm{SOX} 9+$ reactive astrocytes also express GFAP, we observed SOX9+/GFAP - cells in the cortex of the MCAO mouse model and these cells can be labeled by a broader astrocyte marker, $\mathrm{S} 100 \beta$. This is consistent with previous reports that a substantial population of $S 100 \beta+$ / GFAP - astrocytes near the injury site in mouse cortex maintain a GFAP - phenotype after injury (Wang and Walz, 2003; Sirko et al., 2015). Further comparison of the molecular features and functions of SOX9+/S100+/GFAP - and SOX9+/S100+/GFAP+ reactive astrocytes in different CNS regions and in different disease models can be helpful to understand the heterogeneous roles of astrocytes in CNS disease.

Using SOX9-EGFP reporter mice, we purified SOX9+ cells and compared the transcriptional profiles of SOX9+ and GLT1 + astrocytes. Sample distance analysis based on global gene expression, unsupervised hierarchical clustering on top variable genes, and marker gene expression supported the notion that the transcriptome of SOX9+ cells and GLT1 + astrocytes are directly comparable. Therefore, the SOX9-EGFP mouse can be used as a new tool for isolating astrocytes for genomic studies, as well as in vitro experiments. A recent publication showed that RNA profiling from single nuclei is analogous to RNA harvested from the whole cell (Grindberg et al., 2013). Isolation of SOX9immunolabeled nuclei could thereby potentially be useful for RNA-seq and epigenetic studies in astrocytes harvested from the human brain. One advantage of using nuclear RNA is that it may be associated with fewer cell-loss-induced biases because nuclei are more resistant to tissue dissociation than the plasma membrane,and may still be isolated when the plasma membrane is disrupted (Rowat et al., 2006; Matevossian and Akbarian, 2008).

SOX9 is a member of a highly conserved family of transcription factors defined by their similarity to the high-mobility group DNA-binding domain of SRY (sex-determining region Y). SOX9 was first identified as the gene underlying human haploinsufficiency disease campomelic dysplasia (CD), a severe dwarfism syndrome featured by male sex reversal and skeletal malformation of endochondral bones, as well as mental retardation. Brain abnormalities are observed in $\mathrm{CD}$, including dilation of lateral ventricles, hypoplasia of the corpus callosum, and cerebellum defects (Houston et al., 1983). Other studies have documented that SOX9 plays important roles during the development of nervous system and especially in glial fate specification. SOX9 drives fate specification of both astrocytes and oligodendrocyte lineage

\footnotetext{
$\leftarrow$

(Figure legend continued.) CNS region, NeuN + cells are gated according to isotype control staining of that region. Only the gated single nuclei population was analyzed. The percentages for the gated populations are shown in the gate. $\boldsymbol{D}$, Statistical analysis of the percentages of $\mathrm{NeuN}+$ cells for each CNS structure (dark blue bars). Result from a previous study (Fu et al., 2015 ) is plotted in the light blue bars. Error bar indicates SD. $n=5$ mice. $E$, Proportions of SOX9+ cells in the olfactory bulb, cortex, hippocampus, cerebellum, spinal cord, and the rest of the brain. For each CNS structure, $\mathrm{SOX9}+$ cells are gated according to isotype antibody-labeled nuclei samples from that region. Only the single nuclei population was analyzed. The control plot for the cerebral cortex is shown. The percentages for the gated populations are shown in the gates. $F$, Statistical analysis of the percentages of SOX9 + cells for each CNS structure. Error bar indicates SD. $n=5$ mice.
}

cells during development (Stolt et al., 2003; Rowitch and Kriegstein, 2010; Molofsky et al., 2013; Bayraktar et al., 2014; Nagao et al., 2016). For example, Molofsky et al. (2013) used transcriptome analysis of Aldh1l1 precursors harvested from the developing spinal cord to identify candidate transcription factors that serve as regulators of glial fate. The analysis revealed that the bZIP transcription factor Nfe211 promotes glial fate under direct Sox 9 regulatory control. Another study found that Sox9 and NFIA associate physically and collaborate to control the induction and choice of glial-specific genes. Functional analysis revealed that a subset of these genes, Apcdd1 and Mmd2, play key roles in migration and metabolism during gliogenesis, respectively (Kang et al., 2012). Therefore, it is increasingly acknowledged that SOX9 is a key upstream player in the transcriptional cascades that coordinate glial lineage development.

However, despite these findings, it is also clear that the function of SOX9 in the adult CNS is poorly understood. Our study serves not to address this important question, but rather to define SOX9 as an astrocyte-specific nuclear marker, as well as a marker for astroglial lineage neural precursors within the neurogenic zones of the adult murine brain. SOX9 has been proposed to be a master regulator of extracellular matrix production by chondrocytes during chondrogenesis (Pritchett et al., 2011). Consistent with this, it has been found recently that SOX9 is involved in the production of axon-prohibitive extracellular matrix after spinal cord injury and that conditional ablation of SOX9 expression improved functional recovery (McKillop et al., 2013). Accordingly, SOX9 may also regulate extracellular matrix production in astrocytes, which in turn modulate synaptic plasticity under physiological conditions (Faissner et al., 2010). Conversely, SOX9 is downregulated in the dorsal lateral prefrontal cortex of individuals who died after suicide compared with sudden death controls (Ernst et al., 2011; Nagy et al., 2015). The above study suggested a role of SOX9 and thereby of astrocytes in psychiatric disease.

Capitalizing upon our identification of SOX9 as an astrocytespecific nuclear marker, we used the isotropic fractionator technique in combination with SOX9 immunolabeling to quantify the relative proportion of astrocytes in multiple regions of the mouse brain. Our analysis suggests that the relative fraction of astrocytes is lower than expected. SOX $9+$ cells account for $\sim 10-$ $20 \%$ of all cells in most regions of the CNS and only $\sim 3-5 \%$ in the olfactory bulb and cerebellum. Herculano-Houzel and Lent (2005) and Azevedo et al. (2009) first established the technique of isotropic fractionator and suggested that the human brain contains an approximately equal total number of non-neuronal cells (glial) and neurons. The 1:1 ratio of neurons to non-neuronal cells (glia) was recently validated by stereology (Bahney and von Bartheld, 2014). Another stereological study quantified glia subtypes in postmortem human neocortex based on morphology and reported that astrocytes comprise only $\sim 20 \%$ of all glial cells (Pelvig et al., 2008), similar to our data (Fig. 8E,F). Together, these observations suggest both the validity and utility of SOX9based astrocytic identification and isolation.

\section{References}

Alvarez-Buylla A, Temple S (1998) Stem cells in the developing and adult nervous system. J Neurobiol 36:105-110. Medline

Azevedo FA, Carvalho LR, Grinberg LT, Farfel JM, Ferretti RE, Leite RE, Jacob Filho W, Lent R, Herculano-Houzel S (2009) Equal numbers of neuronal and nonneuronal cells make the human brain an isometrically scaled-up primate brain. J Comp Neurol 513:532-541. CrossRef Medline Bahney J, von Bartheld CS (2014) Validation of the isotropic fractionator: 
comparison with unbiased stereology and DNA extraction for quantification of glial cells. J Neurosci Methods 222:165-174. CrossRef Medline

Ballabh P, Braun A, Nedergaard M (2004) The blood-brain barrier: an overview: structure, regulation, and clinical implications. Neurobiol Dis 16:113. CrossRef Medline

Bardehle S, Krüger M, Buggenthin F, Schwausch J, Ninkovic J, Clevers H, Snippert HJ, Theis FJ, Meyer-Luehmann M, Bechmann I, Dimou L, Götz M (2013) Live imaging of astrocyte responses to acute injury reveals selective juxtavascular proliferation. Nat Neurosci 16:580-586. CrossRef Medline

Barnabé-Heider F, Göritz C, Sabelström H, Takebayashi H, Pfrieger FW, Meletis K, Frisén J (2010) Origin of new glial cells in intact and injured adult spinal cord. Cell Stem Cell 7:470-482. CrossRef Medline

Bayraktar OA, Fuentealba LC, Alvarez-Buylla A, Rowitch DH (2014) Astrocyte development and heterogeneity. Cold Spring Harb Perspect Biol 7:a020362. CrossRef Medline

Benraiss A, Wang S, Herrlinger S, Li X, Chandler-Militello D, Mauceri J, Burm HB, Toner M, Osipovitch M, Jim Xu Q, Ding F, Wang F, Kang N, Kang J, Curtin PC, Brunner D, Windrem MS, Munoz-Sanjuan I, Nedergaard M, Goldman SA (2016) Human glia can both induce and rescue aspects of disease phenotype in Huntington disease. Nat Commun 7:11758. CrossRef Medline

Berger UV, DeSilva TM, Chen W, Rosenberg PA (2005) Cellular and subcellular mRNA localization of glutamate transporter isoforms GLT1a and GLT1b in rat brain by in situ hybridization. J Comp Neurol 492:78-89. CrossRef Medline

Bergles DE, Jahr CE (1997) Synaptic activation of glutamate transporters in hippocampal astrocytes. Neuron 19:1297-1308. CrossRef Medline

Bernstein HG, Bannier J, Meyer-Lotz G, Steiner J, Keilhoff G, Dobrowolny H, Walter M, Bogerts B (2014) Distribution of immunoreactive glutamine synthetase in the adult human and mouse brain: qualitative and quantitative observations with special emphasis on extra-astroglial protein localization. J Chem Neuroanat 61-62:33-50. CrossRef Medline

Bushong EA, Martone ME, Ellisman MH (2004) Maturation of astrocyte morphology and the establishment of astrocyte domains during postnatal hippocampal development. Int J Dev Neurosci 22:73-86. CrossRef Medline

Cahoy JD, Emery B, Kaushal A, Foo LC, Zamanian JL, Christopherson KS, Xing Y, Lubischer JL, Krieg PA, Krupenko SA, Thompson WJ, Barres BA (2008) A transcriptome database for astrocytes, neurons, and oligodendrocytes: a new resource for understanding brain development and function. J Neurosci 28:264-278. CrossRef Medline

Cheng LC, Pastrana E, Tavazoie M, Doetsch F (2009) miR-124 regulates adult neurogenesis in the subventricular zone stem cell niche. Nat Neurosci 12:399-408. CrossRef Medline

Collins CE, Young NA, Flaherty DK, Airey DC, Kaas JH (2010) A rapid and reliable method of counting neurons and other cells in brain tissue: a comparison of flow cytometry and manual counting methods. Front Neuroanat 4:5. CrossRef Medline

Doetsch F, Caillé I, Lim DA, García-Verdugo JM, Alvarez-Buylla A (1999) Subventricular zone astrocytes are neural stem cells in the adult mammalian brain. Cell 97:703-716. CrossRef Medline

Doyle JP, Dougherty JD, Heiman M, Schmidt EF, Stevens TR, Ma G, Bupp S, Shrestha P, Shah RD, Doughty ML, Gong S, Greengard P, Heintz N (2008) Application of a translational profiling approach for the comparative analysis of CNS cell types. Cell 135:749-762. CrossRef Medline

Dunlop J, Beal Mcllvain H, She Y, Howland DS (2003) Impaired spinal cord glutamate transport capacity and reduced sensitivity to riluzole in a transgenic superoxide dismutase mutant rat model of amyotrophic lateral sclerosis. J Neurosci 23:1688-1696. Medline

Ernst C, Nagy C, Kim S, Yang JP, Deng X, Hellstrom IC, Choi KH, Gershenfeld H, Meaney MJ, Turecki G (2011) Dysfunction of astrocyte connexins 30 and 43 in dorsal lateral prefrontal cortex of suicide completers. Biol Psychiatry 70:312-319. CrossRef Medline

Faissner A, Pyka M, Geissler M, Sobik T, Frischknecht R, Gundelfinger ED, Seidenbecher C (2010) Contributions of astrocytes to synapse formation and maturation: potential functions of the perisynaptic extracellular matrix. Brain Res Rev 63:26-38. CrossRef Medline

Farmer WT, Abrahamsson T, Chierzi S, Lui C, Zaelzer C, Jones EV, Bally BP, Chen GG, Théroux JF, Peng J, Bourque CW, Charron F, Ernst C, Sjöström PJ, Murai KK (2016) Neurons diversify astrocytes in the adult brain through sonic hedgehog signaling. Science 351:849-854. CrossRef Medline
Filippov V, Kronenberg G, Pivneva T, Reuter K, Steiner B, Wang LP, Yamaguchi M, Kettenmann H, Kempermann G (2003) Subpopulation of nestin-expressing progenitor cells in the adult murine hippocampus shows electrophysiological and morphological characteristics of astrocytes. Mol Cell Neurosci 23:373-382. CrossRef Medline

Fischer AJ, Zelinka C, Scott MA (2010) Heterogeneity of glia in the retina and optic nerve of birds and mammals. PLoS One 5:e10774. CrossRef Medline

Fu Y, Yu Y, Paxinos G, Watson C, Rusznák Z (2015) Aging-dependent changes in the cellular composition of the mouse brain and spinal cord. Neuroscience 290:406-420. CrossRef Medline

Goldman SA, Sim F 2005 Neural progenitor cells of the adult brain. Novartis Found Symp 265:66-80; discussion 82-97. Medline

Gong S, Zheng C, Doughty ML, Losos K, Didkovsky N, Schambra UB, Nowak NJ, Joyner A, Leblanc G, Hatten ME, Heintz N (2003) A gene expression atlas of the central nervous system based on bacterial artificial chromosomes. Nature 425:917-925. CrossRef Medline

Gourine AV, Kasymov V, Marina N, Tang F, Figueiredo MF, Lane S, Teschemacher AG, Spyer KM, Deisseroth K, Kasparov S (2010) Astrocytes control breathing through $\mathrm{pH}$-dependent release of ATP. Science 329: 571-575. CrossRef Medline

Grindberg RV, Yee-Greenbaum JL, McConnell MJ, Novotny M, O'Shaughnessy AL, Lambert GM, Araúzo-Bravo MJ, Lee J, Fishman M, Robbins GE, Lin X, Venepally P, Badger JH, Galbraith DW, Gage FH, Lasken RS (2013) RNA-sequencing from single nuclei. Proc Natl Acad Sci U S A 110:19802-19807. CrossRef Medline

Heiman M, Schaefer A, Gong S, Peterson JD, Day M, Ramsey KE, SuárezFariñas M, Schwarz C, Stephan DA, Surmeier DJ, Greengard P, Heintz N (2008) A translational profiling approach for the molecular characterization of CNS cell types. Cell 135:738-748. CrossRef Medline

Herculano-Houzel S, Lent R (2005) Isotropic fractionator: a simple, rapid method for the quantification of total cell and neuron numbers in the brain. J Neurosci 25:2518-2521. CrossRef Medline

Hilgetag CC, Barbas H (2009) Are there ten times more glia than neurons in the brain? Brain Struct Funct 213:365-366. CrossRef Medline

Horner PJ, Gage FH (2000) Regenerating the damaged central nervous system. Nature 407:963-970. CrossRef Medline

Houston CS, Opitz JM, Spranger JW, Macpherson RI, Reed MH, Gilbert EF, Herrmann J, Schinzel A (1983) The campomelic syndrome: review, report of 17 cases, and follow-up on the currently 17-year-old boy first reported by Maroteaux et al in 1971. Am J Med Genet 15:3-28. CrossRef Medline

Iliff JJ, Wang M, Liao Y, Plogg BA, Peng W, Gundersen GA, Benveniste H, Vates GE, Deane R, Goldman SA, Nagelhus EA, Nedergaard M (2012) A paravascular pathway facilitates CSF flow through the brain parenchyma and the clearance of interstitial solutes, including amyloid beta. Sci Transl Med 4:147ra111. CrossRef Medline

Kandel ER, Schwartz JH, Jessell TM (2000) Principles of neural science, Ed 4. New York: McGraw-Hill.

Kang J, Jiang L, Goldman SA, Nedergaard M (1998) Astrocyte-mediated potentiation of inhibitory synaptic transmission. Nat Neurosci 1:683692. CrossRef Medline

Kang P, Lee HK, Glasgow SM, Finley M, Donti T, Gaber ZB, Graham BH, Foster AE, Novitch BG, Gronostajski RM, Deneen B (2012) Sox9 and NFIA coordinate a transcriptional regulatory cascade during the initiation of gliogenesis. Neuron 74:79-94. CrossRef Medline

Kronenberg G, Reuter K, Steiner B, Brandt MD, Jessberger S, Yamaguchi M, Kempermann G (2003) Subpopulations of proliferating cells of the adult hippocampus respond differently to physiologic neurogenic stimuli. J Comp Neurol 467:455-463. CrossRef Medline

Kuffler SW, Nicholls JG (1966) The physiology of neuroglial cells. In: Ergebnisse der Physiologie Biologischen Chemie und Experimentellen Pharmakologie (Asher L, Spiro K, eds), pp 1-90. Berlin/Heidelberg: Springer.

Lovatt D, Sonnewald U, Waagepetersen HS, Schousboe A, He W, Lin JH, Han X, Takano T, Wang S, Sim FJ, Goldman SA, Nedergaard M (2007) The transcriptome and metabolic gene signature of protoplasmic astrocytes in the adult murine cortex. J Neurosci 27:12255-12266. CrossRef Medline

Matevossian A, Akbarian S (2008) Neuronal nuclei isolation from human postmortem brain tissue. J Vis Exp 20: pii: 914. CrossRef Medline

McKillop WM, Dragan M, Schedl A, Brown A (2013) Conditional Sox9 ablation reduces chondroitin sulfate proteoglycan levels and improves motor function following spinal cord injury. Glia 61:164-177. CrossRef Medline 
McKillop WM, York EM, Rubinger L, Liu T, Ossowski NM, Xu K, Hryciw T, Brown A (2016) Conditional Sox9 ablation improves locomotor recovery after spinal cord injury by increasing reactive sprouting. Exp Neurol 283:1-15. CrossRef Medline

Molofsky AV, Krenick R, Ullian E, Tsai HH, Deneen B, Richardson WD, Barres BA, Rowitch DH (2012) Astrocytes and disease: a neurodevelopmental perspective. Genes Dev 26:891-907. CrossRef Medline

Molofsky AV, Glasgow SM, Chaboub LS, Tsai HH, Murnen AT, Kelley KW, Fancy SP, Yuen TJ, Madireddy L, Baranzini S, Deneen B, Rowitch DH, Oldham MC (2013) Expression profiling of Aldh1l1-precursors in the developing spinal cord reveals glial lineage-specific genes and direct Sox9Nfe2l1 interactions. Glia 61:1518-1532. CrossRef Medline

Nagao M, Ogata T, Sawada Y, Gotoh Y (2016) Zbtb20 promotes astrocytogenesis during neocortical development. Nat Commun 7:11102. CrossRef Medline

Nagy C, Suderman M, Yang J, Szyf M, Mechawar N, Ernst C, Turecki G (2015) Astrocytic abnormalities and global DNA methylation patterns in depression and suicide. Mol Psychiatry 20:320-328. CrossRef Medline

Nagy JI, Patel D, Ochalski PA, Stelmack GL (1999) Connexin30 in rodent, cat and human brain: selective expression in gray matter astrocytes, colocalization with connexin 43 at gap junctions and late developmental appearance. Neuroscience 88:447-468. CrossRef Medline

Nedergaard M (1994) Direct signaling from astrocytes to neurons in cultures of mammalian brain cells. Science 263:1768-1771. CrossRef Medline

Nedergaard M, Ransom B, Goldman SA (2003) New roles for astrocytes: redefining the functional architecture of the brain. Trends Neurosci 26: 523-530. CrossRef Medline

Oberheim NA, Tian GF, Han X, Peng W, Takano T, Ransom B, Nedergaard M (2008) Loss of astrocytic domain organization in the epileptic brain. J Neurosci 28:3264-3276. CrossRef Medline

Parpura V, Basarsky TA, Liu F, Jeftinija K, Jeftinija S, Haydon PG (1994) Glutamate-mediated astrocyte-neuron signalling. Nature 369:744-747. CrossRef Medline

Pelvig DP, Pakkenberg H, Stark AK, Pakkenberg B (2008) Neocortical glial cell numbers in human brains. Neurobiol Aging 29:1754-1762. CrossRef Medline

Pompolo S, Harley VR (2001) Localisation of the SRY-related HMG box protein, SOX9, in rodent brain. Brain Res 906:143-148. CrossRef Medline

Pritchett J, Athwal V, Roberts N, Hanley NA, Hanley KP (2011) Understanding the role of SOX9 in acquired diseases: lessons from development. Trends Mol Med 17:166-174. CrossRef Medline

Regan MR, Huang YH, Kim YS, Dykes-Hoberg MI, Jin L, Watkins AM, Bergles DE, Rothstein JD (2007) Variations in promoter activity reveal a differential expression and physiology of glutamate transporters by glia in the developing and mature CNS. J Neurosci 27:6607-6619. CrossRef Medline

Rothstein JD, Martin L, Levey AI, Dykes-Hoberg M, Jin L, Wu D, Nash N, Kuncl RW (1994) Localization of neuronal and glial glutamate transporters. Neuron 13:713-725. CrossRef Medline

Rowat AC, Lammerding J, Ipsen JH (2006) Mechanical properties of the cell nucleus and the effect of emerin deficiency. Biophys J 91:4649-4664. CrossRef Medline

Rowitch DH, Kriegstein AR (2010) Developmental genetics of vertebrate glial-cell specification. Nature 468:214-222. CrossRef Medline

Ruscher K, Johannesson E, Brugiere E, Erickson A, Rickhag M, Wieloch T (2009) Enriched environment reduces apolipoprotein E (ApoE) in reactive astrocytes and attenuates inflammation of the peri-infarct tissue after experimental stroke. J Cereb Blood Flow Metab 29:1796-1805. CrossRef Medline

Schmitt A, Asan E, Püschel B, Jöns T, Kugler P (1996) Expression of the glutamate transporter GLT1 in neural cells of the rat central nervous system: non-radioactive in situ hybridization and comparative immunocytochemistry. Neuroscience 71:989-1004. CrossRef Medline
Scott CE, Wynn SL, Sesay A, Cruz C, Cheung M, Gomez Gaviro MV, Booth S, Gao B, Cheah KS, Lovell-Badge R, Briscoe J (2010) SOX9 induces and maintains neural stem cells. Nat Neurosci 13:1181-1189. CrossRef Medline

Sirko S, Irmler M, Gascón S, Bek S, Schneider S, Dimou L, Obermann J, De Souza Paiva D, Poirier F, Beckers J, Hauck SM, Barde YA, Götz M (2015) Astrocyte reactivity after brain injury: the role of galectins 1 and 3. Glia 63:2340-2361. CrossRef Medline

Sofroniew MV, Vinters HV (2010) Astrocytes: biology and pathology. Acta Neuropathol 119:7-35. CrossRef Medline

Steiner J, Bernstein HG, Bielau H, Berndt A, Brisch R, Mawrin C, Keilhoff G, Bogerts B (2007) Evidence for a wide extra-astrocytic distribution of S100B in human brain. BMC Neurosci 8:2. CrossRef Medline

Stolt CC, Lommes P, Sock E, Chaboissier MC, Schedl A, Wegner M (2003) The Sox 9 transcription factor determines glial fate choice in the developing spinal cord. Genes Dev 17:1677-1689. CrossRef Medline

Sun W, McConnell E, Pare JF, Xu Q, Chen M, Peng W, Lovatt D, Han X, Smith Y, Nedergaard M (2013) Glutamate-dependent neuroglial calcium signaling differs between young and adult brain. Science 339:197200. CrossRef Medline

Takata N, Mishima T, Hisatsune C, Nagai T, Ebisui E, Mikoshiba K, Hirase H (2011) Astrocyte calcium signaling transforms cholinergic modulation to cortical plasticity in vivo. J Neurosci 31:18155-18165. CrossRef Medline

van Landeghem FK, Weiss T, Oehmichen M, von Deimling A (2006) Decreased expression of glutamate transporters in astrocytes after human traumatic brain injury. J Neurotrauma 23:1518-1528. CrossRef Medline

Verkhratsky A, Matteoli M, Parpura V, Mothet JP, Zorec R (2016) Astrocytes as secretory cells of the central nervous system: idiosyncrasies of vesicular secretion. EMBO J 35:239-257. CrossRef Medline

Walz W, Lang MK (1998) Immunocytochemical evidence for a distinct GFAP-negative subpopulation of astrocytes in the adult rat hippocampus. Neurosci Lett 257:127-130. CrossRef Medline

Wang K, Walz W (2003) Unusual topographical pattern of proximal astrogliosis around a cortical devascularizing lesion. J Neurosci Res 73:497506. CrossRef Medline

Wang M, Iliff JJ, Liao Y, Chen MJ, Shinseki MS, Venkataraman A, Cheung J, Wang W, Nedergaard M (2012) Cognitive deficits and delayed neuronal loss in a mouse model of multiple microinfarcts. J Neurosci 32:1794817960. CrossRef Medline

Yang Y, Vidensky S, Jin L, Jie C, Lorenzini I, Frankl M, Rothstein JD (2011) Molecular comparison of GLT1 + and ALDH1L1+ astrocytes in vivo in astroglial reporter mice. Glia 59:200-207. CrossRef Medline

Yang Z, Wang KK (2015) Glial fibrillary acidic protein: from intermediate filament assembly and gliosis to neurobiomarker. Trends Neurosci 38: 364-374. CrossRef Medline

Zeisel A, Muñoz-Manchado AB, Codeluppi S, Lönnerberg P, La Manno G, Juréus A, Marques S, Munguba H, He L, Betsholtz C, Rolny C, CasteloBranco G, Hjerling-Leffler J, Linnarsson S (2015) Brain structure: cell types in the mouse cortex and hippocampus revealed by single-cell RNAseq. Science 347:1138-1142. CrossRef Medline

Zhang Y, Chen K, Sloan SA, Bennett ML, Scholze AR, O'Keeffe S, Phatnani HP, Guarnieri P, Caneda C, Ruderisch N, Deng S, Liddelow SA, Zhang C, Daneman R, Maniatis T, Barres BA, Wu JQ (2014) An RNA-sequencing transcriptome and splicing database of glia, neurons, and vascular cells of the cerebral cortex. J Neurosci 34:11929-11947. CrossRef Medline

Zhang Y, Sloan SA, Clarke LE, Caneda C, Plaza CA, Blumenthal PD, Vogel H, Steinberg GK, Edwards MS, Li G, Duncan JA 3rd, Cheshier SH, Shuer LM, Chang EF, Grant GA, Gephart MG, Barres BA (2016) Purification and characterization of progenitor and mature human astrocytes reveals transcriptional and functional differences with mouse. Neuron 89:37-53. CrossRef Medline 